\title{
ATTITUDES TOWARDS VOCATIONAL TEACHING AND ITS RELATIONSHIP WITH VOCATIONAL INTERESTS AND AWARENESS FOR 10 GRADE STUDENTS IN SULTANATE OF OMAN
}

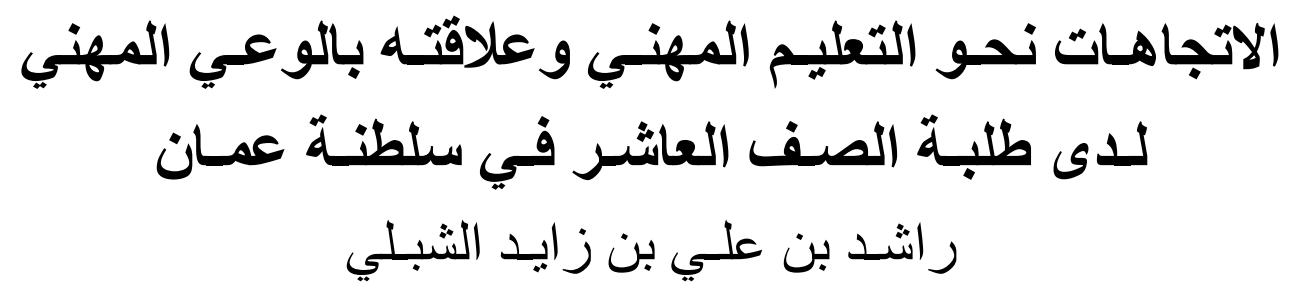

\section{Al-Shibli Rashid Ali Zayid ${ }^{1 *}$, Prof. Dr. Siti Rafiah Abdul Hamid ${ }^{2} \&$} Dr. Fahmi Mostafa Al Bakor ${ }^{3}$

\author{
${ }^{1}$ Ph.D. Candidate at the Faculty of Education, International Islamic University Malaysia (IIUM), \\ rashidalshibli@hotmail.com \\ ${ }^{2}$ Prof. Dr. at the Faculty of Education, International Islamic University Malaysia (IIUM), \\ Srafiah60@iium.edu.my \\ ${ }^{3}$ Senior Lecturer at the Faculty of Education, International Islamic University Malaysia (IIUM), \\ rashid.ali.zaid@gmail.com \\ ${ }^{*}$ Corresponding Author
}

\begin{abstract}
This quantitative study discusses the attitudes of tenth grade students in North Al Batinah governorate towards vocational education, where the problem highlights that the numbers of students enrolled in vocational training are very few, compared to the numbers of students enrolled in general and basic education, the specializations in the professional branches are very few, which do not meet the needs and requirements of the labor market. This is in addition to the lack of awareness among students and their parents of vocational education. Therefore, the aim of the study is to reveal the level of students' attitudes towards vocational education. Knowing their attitudes towards vocational education and its relationship to professional awareness. And reveal the responses of male and female students according to the scale of attitudes towards vocational education. The study adopted the descriptive, relational approach. A random sample of 393 students was chosen from the study population, and 387 students from all six states. Three measures were used: the measure of the trend towards vocational education (30) statements, the scale of occupational awareness (30) statements, the scale of occupational interests (24) statements. The results indicated that students 'attitudes toward vocational education were positive to a low degree, a statistically significant correlation at level $(0.01)$ between the trend towards vocational education, and vocational awareness among the study sample individuals in the vocational awareness scale, and a statistically significant correlation at level $(0.01)$ between the trend towards vocational education, And professional interests of the study sample, and finally, there are no differences between male and female students in the direction towards vocational education.
\end{abstract}

Keywords: student attitudes, vocational education, professional awareness.

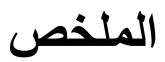

تناقش هذه الدر اسـة الكميـة اتجاهـات طلبـة الصف العاثـر في محافظلة شـمال الباطنة نحو التعليم 


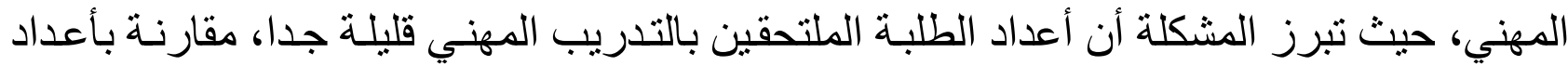

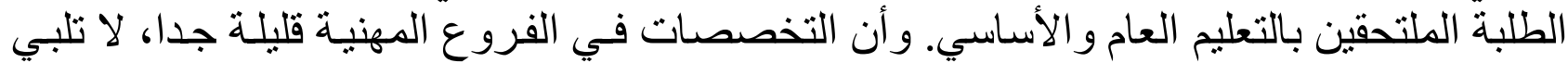

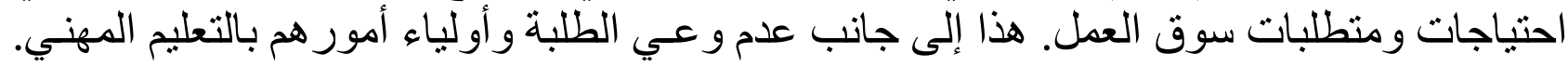

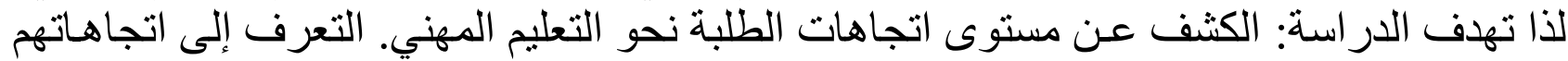

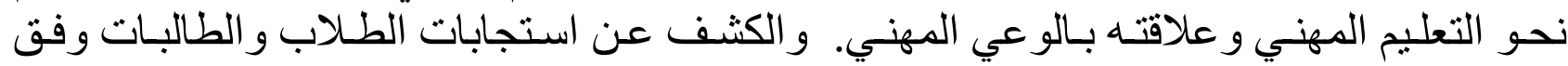

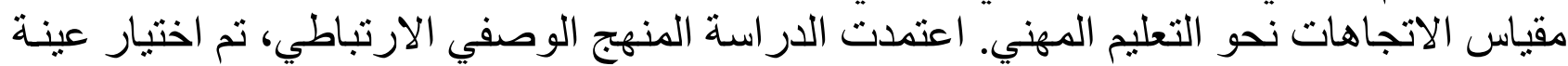

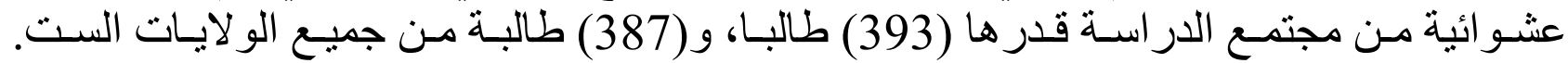

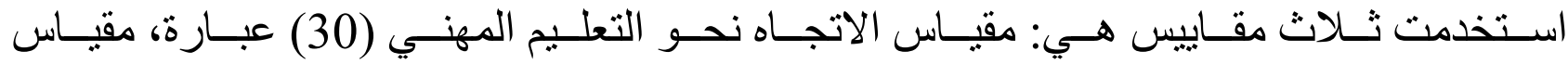

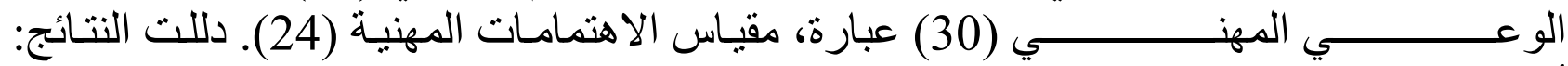

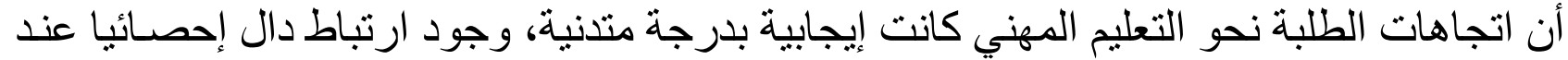

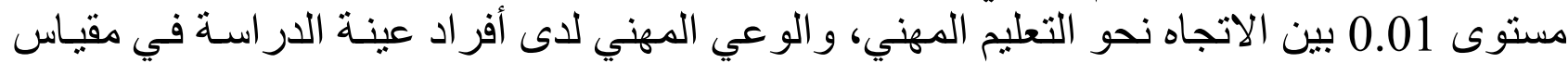

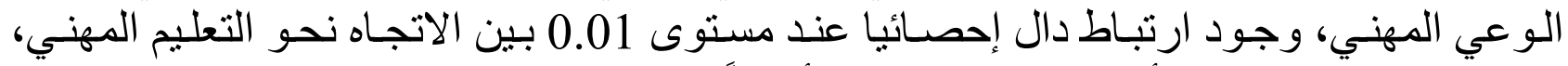

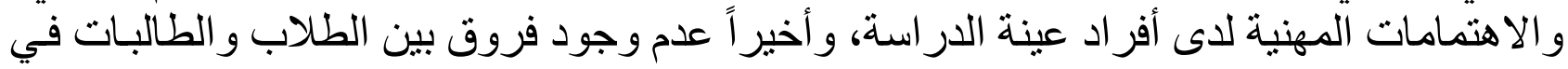
الاتجاه نحو التعليم المهني. كلمات مفتاحية: اتجاهات الطلبة، التعليم المهني، الوعي المهي.

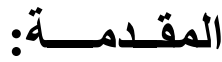

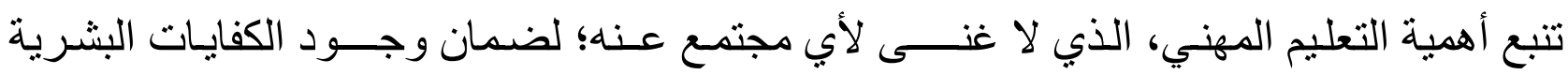

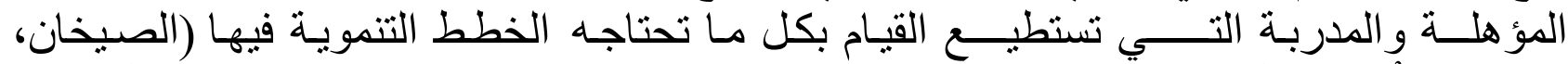

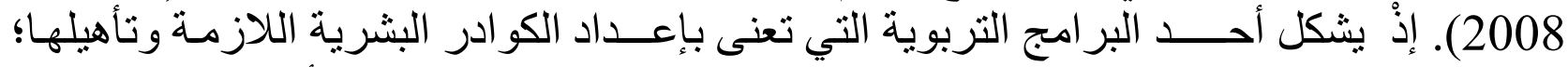

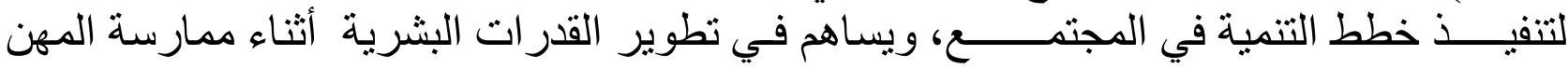

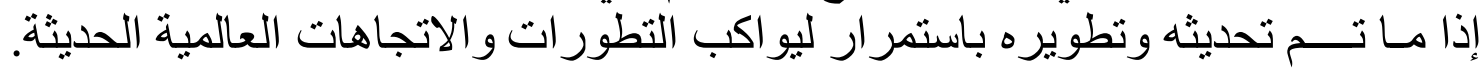

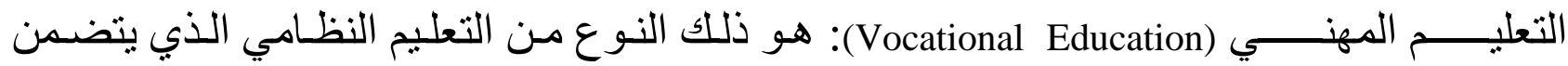

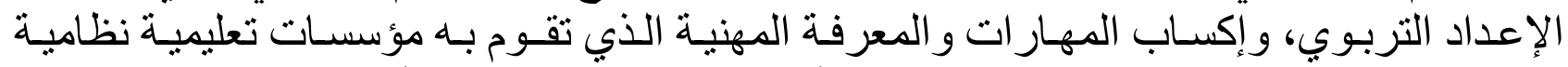

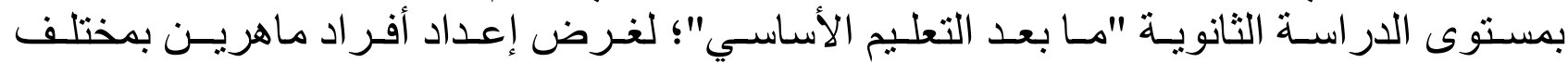

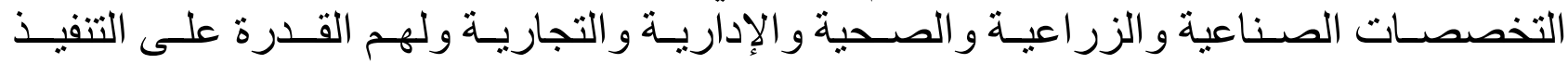

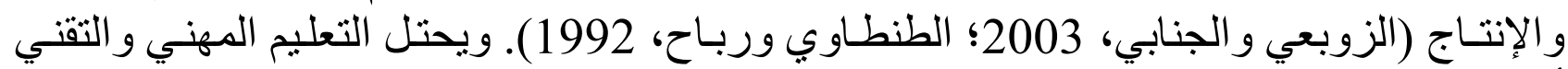

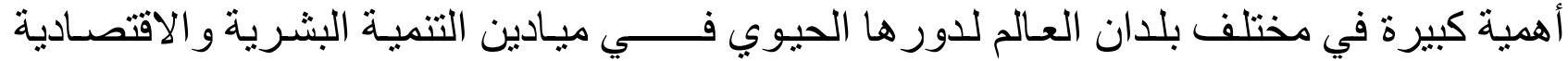

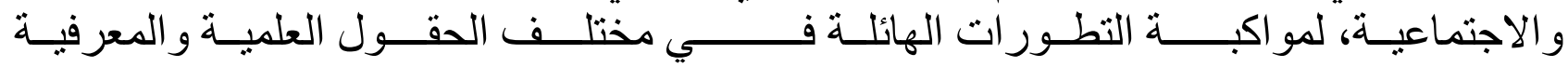
ومستوياتها (داود، 2002).

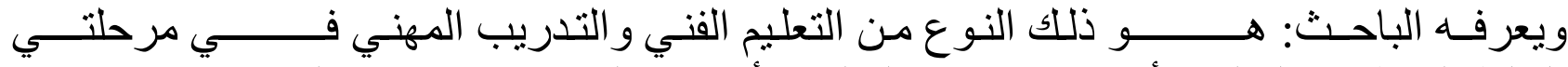

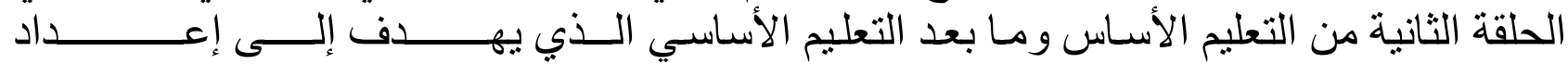

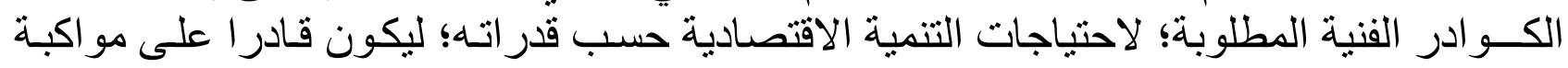

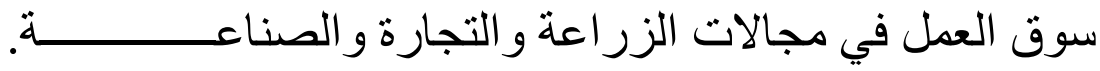


لذللك صـدرت توصسيات عديدة للنهوض بهذا النـوع مـن التعليم تركزت في ضــرورة إدخـال

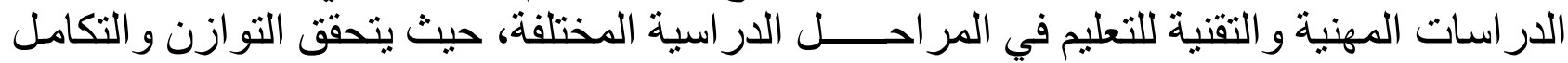
في هذا التعليم. وأكدت التوصبات على دور الأعمـال الحرفيـة و اليدويـة و الدر اسـات التقنيـة الخفيفة

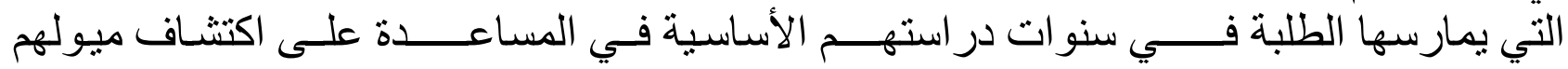

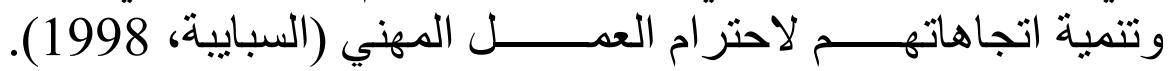

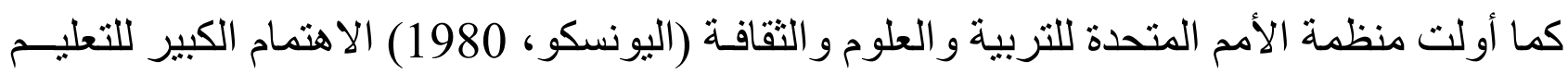

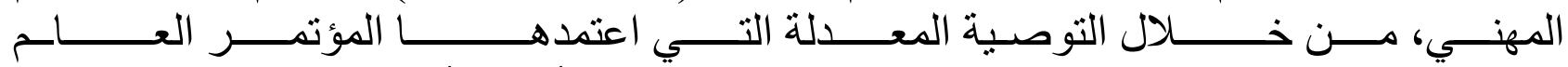

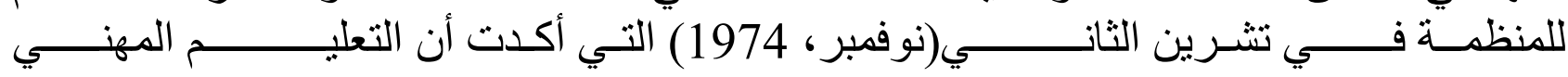

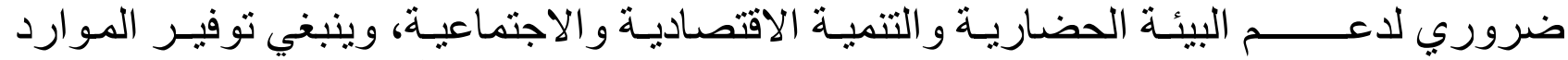

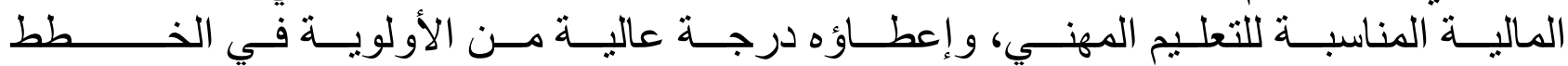
الوطنب.

ونلاحظ أن التوصيات تعكس الاهنمام الكبير على المستوى العـالمي للتعليم المهني لمـا لمخرجاته

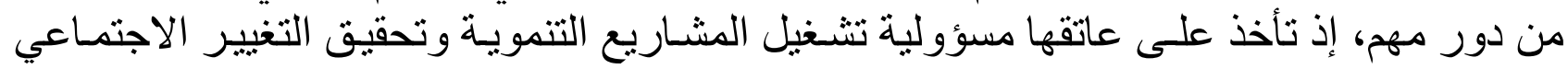

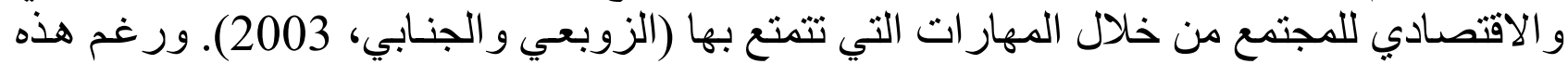

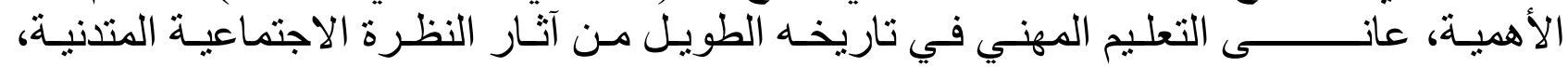

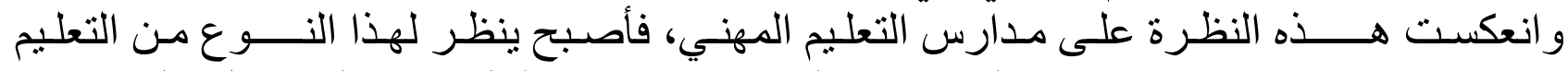

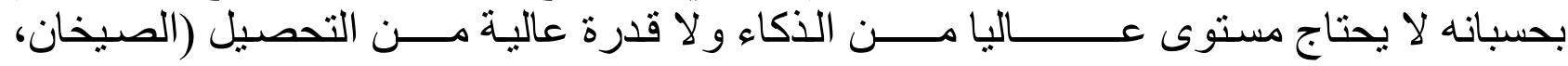

. $(2008$

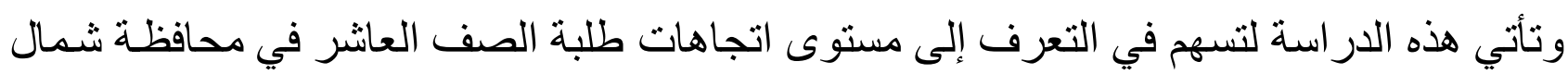

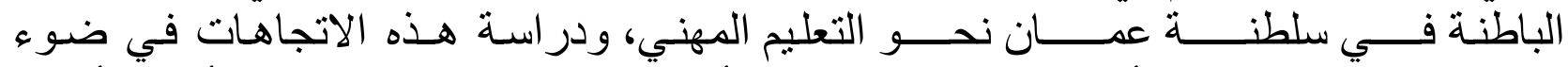

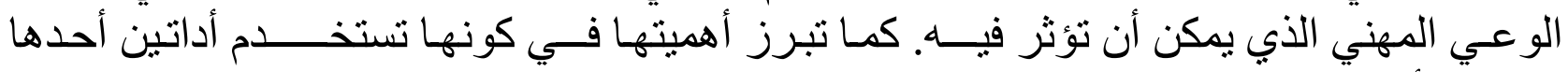

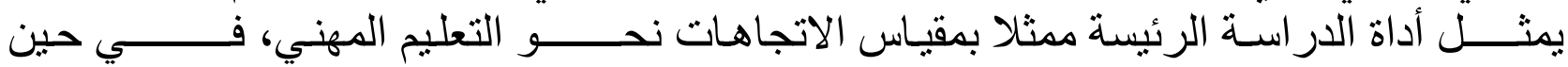

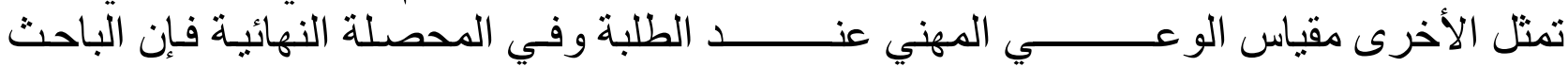

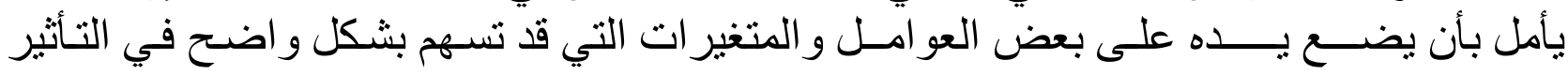

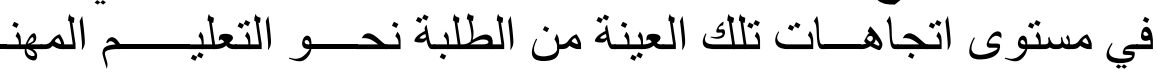
مشكنـة الدراســـة: مئس

بناء على الواقع المعاث الذي يبدو فيه تدني الإقبال على التعليم المهني في السلطنة، حيث إن العديد

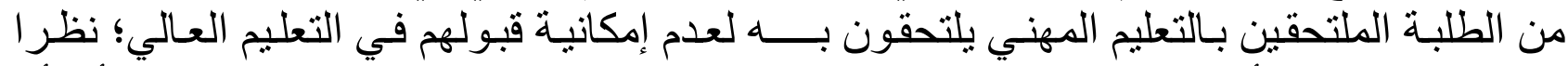

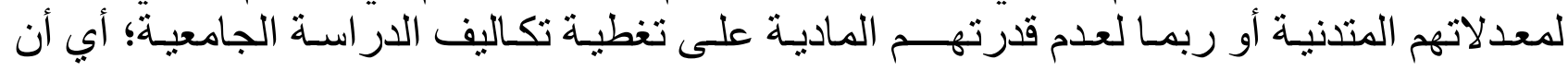

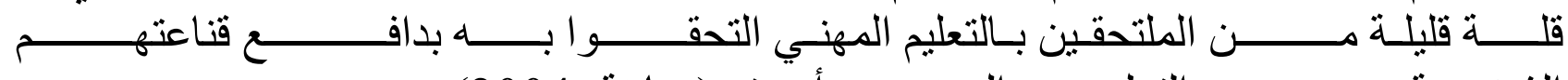

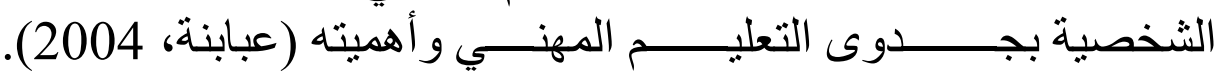
حيث تثنير الإحصـائيات الصـادرة عن وزارة القوى العاملة (2010)، أن أعداد الطلبـة الملتحقين

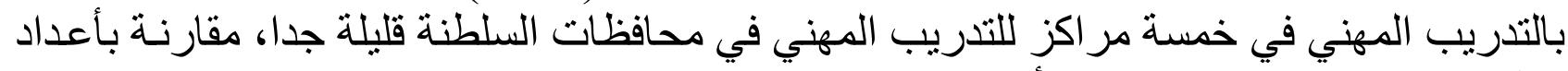

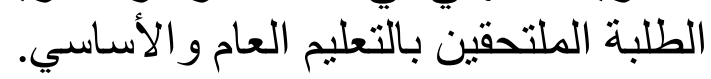
و أن عــــــدد المعاهد المهنية المتو افرة فـــــي السلطنة قليلـة جدا مقارنـة بأعداد مدارس التعليم 


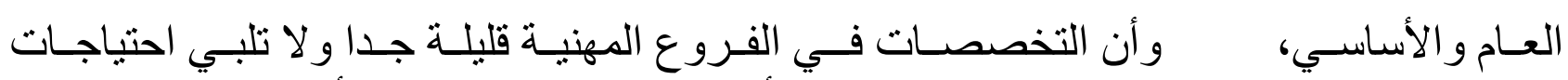

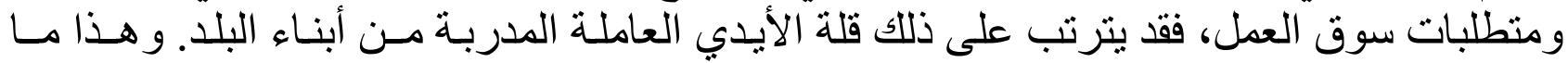

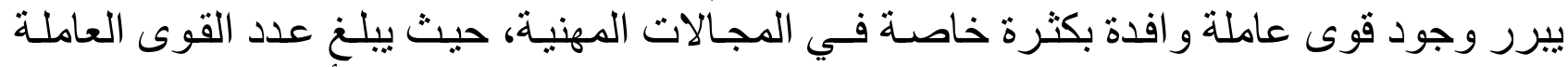

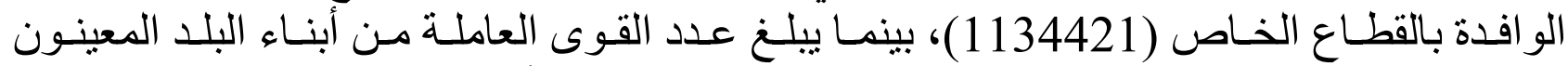

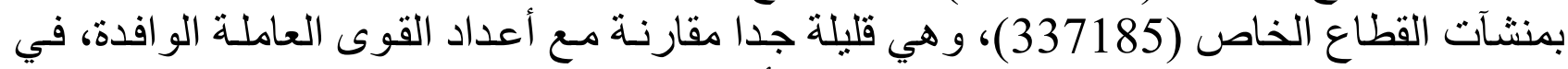

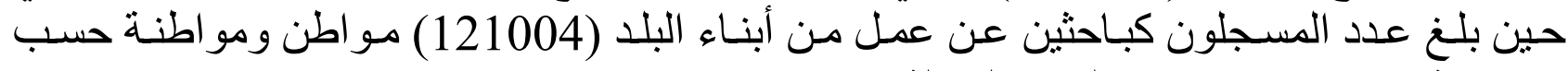
إحصائية (2010). ( وزارة القوى العاملة، 2010).

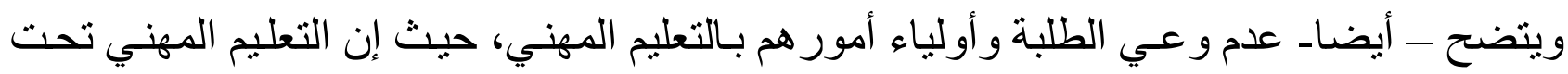

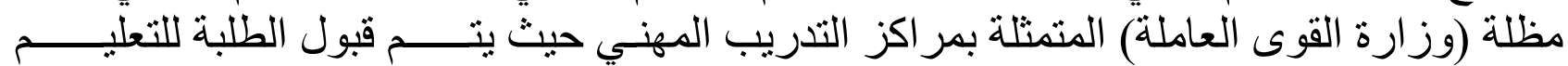

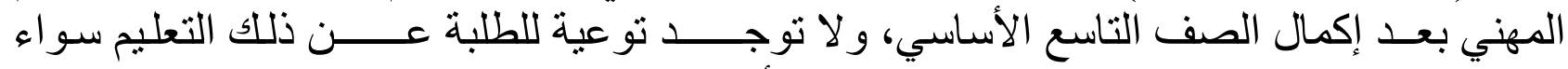

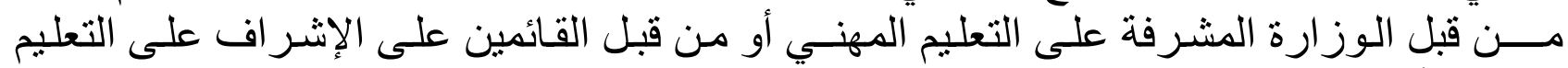

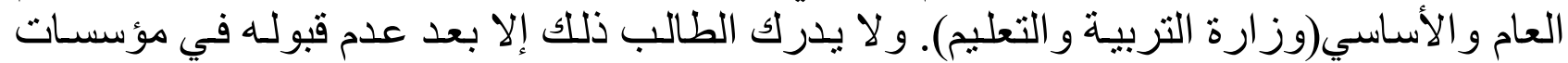
التعليم العالي بعد إنهاء دبلوم التعليم العام.

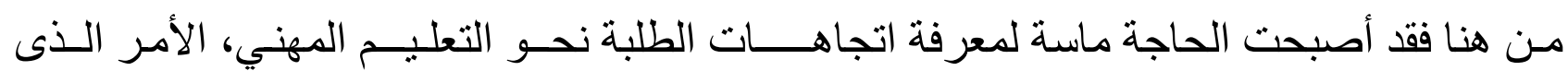

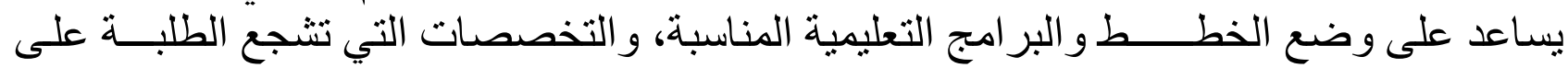

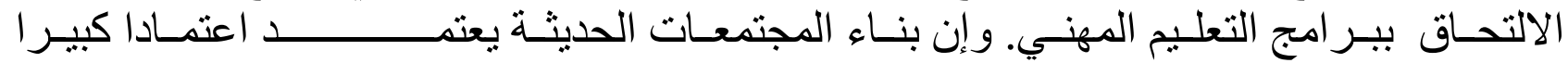

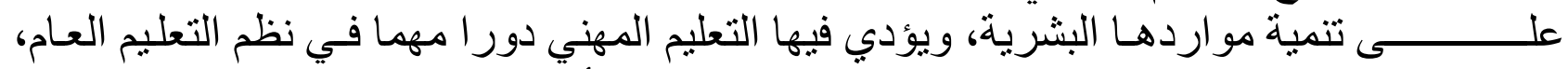

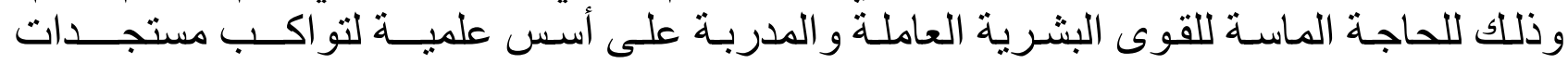

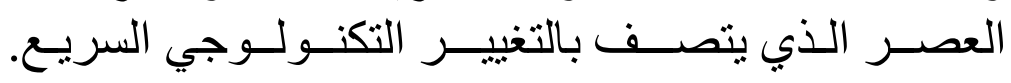

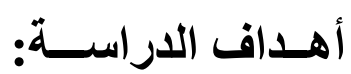

أ. الكثف عن مستوى اتجاهات الطلبة نحو التعليم المهني. ب. التعرف إلى اتجاهات الطلبة نحو التعليم المهني و علاقتها بالوعي المهني.

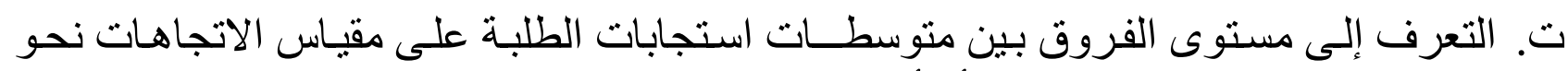
التعليم المهني التي تعزى للنوع التهرى (ذكر أو أنثى).

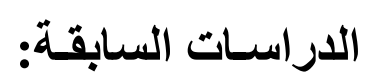

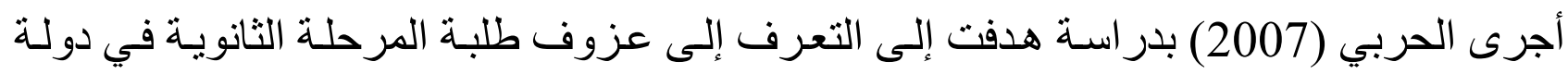

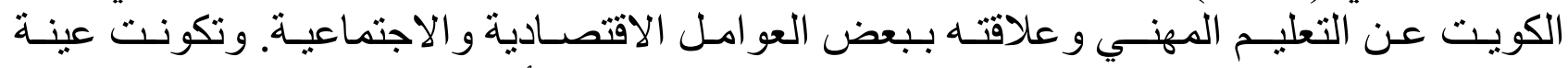

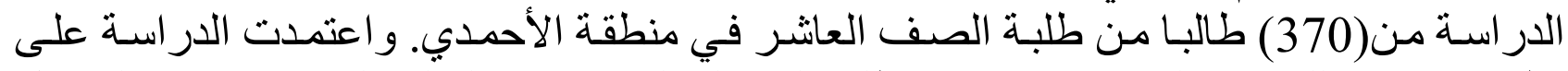

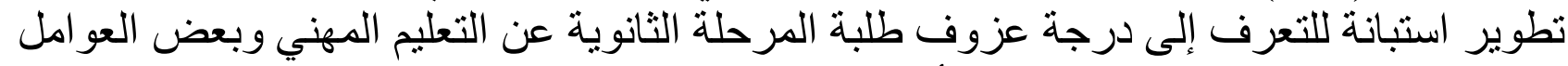

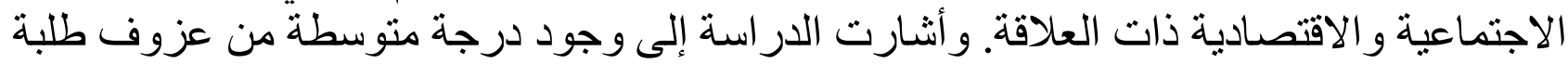

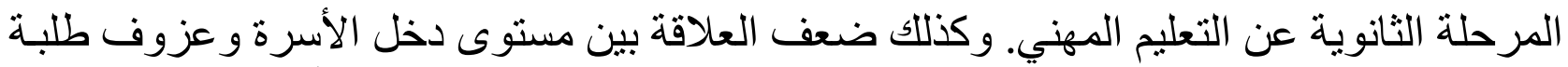

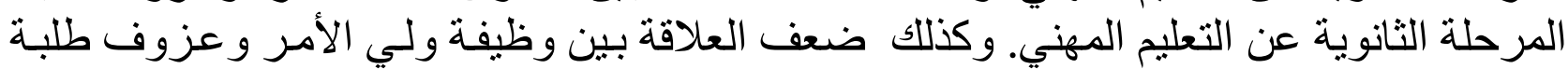

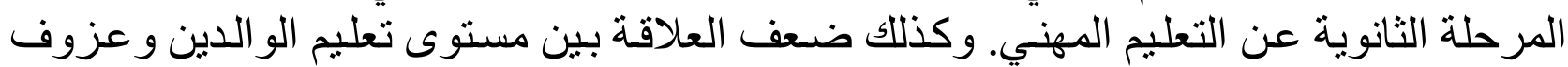

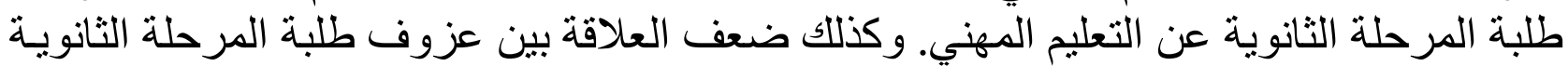

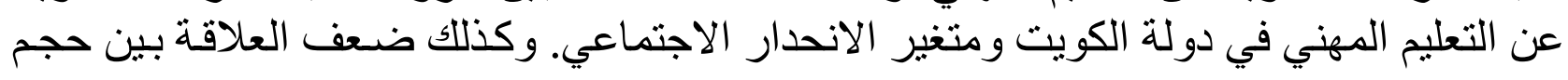


الأسرة و عزوف طلبة المرحلة الثانوية عن التعليم المهني.

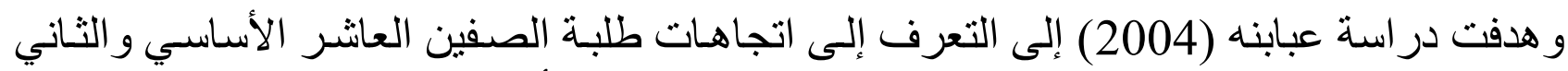

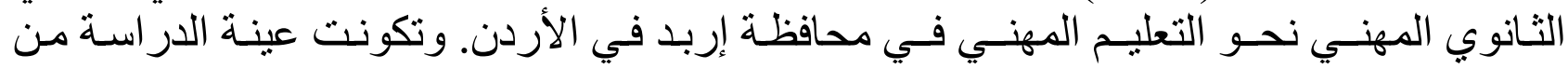

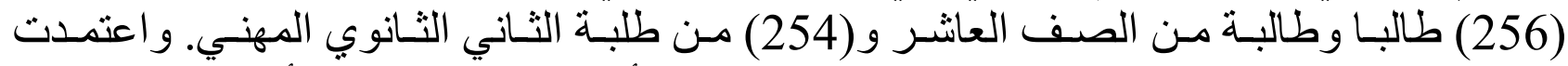

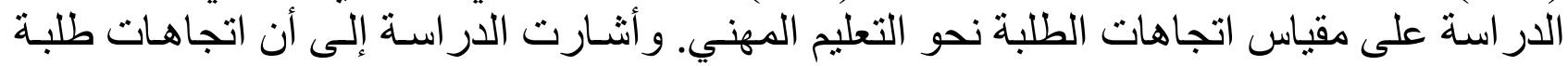

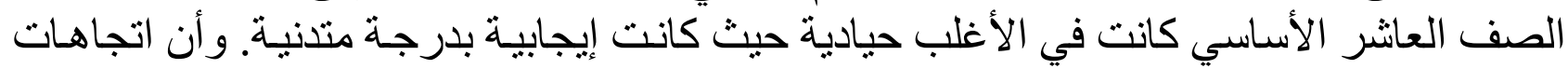

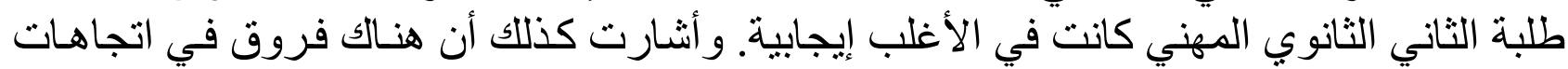

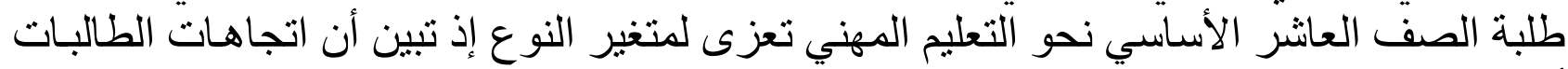

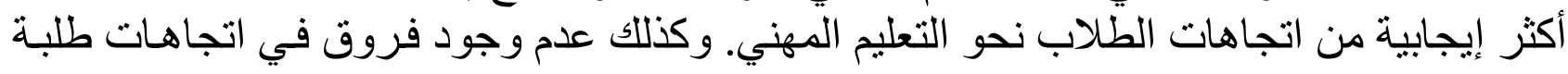

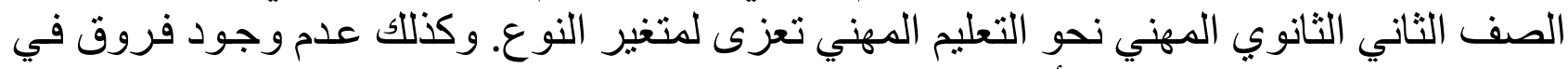

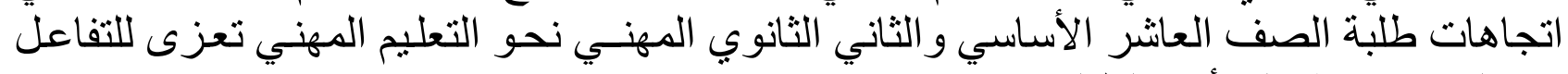
بين النوع ومهنة ولي أمر الطالب.

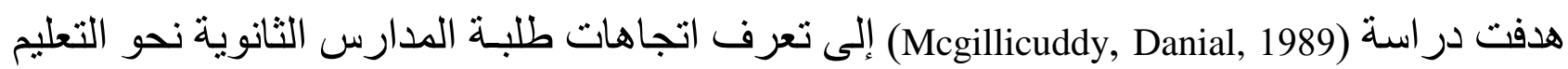

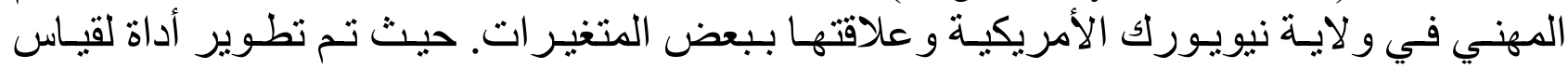

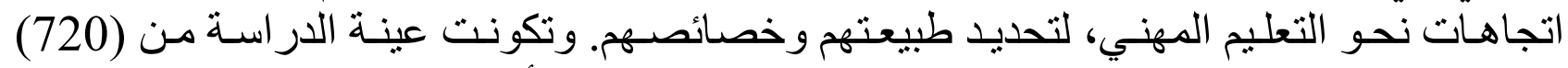

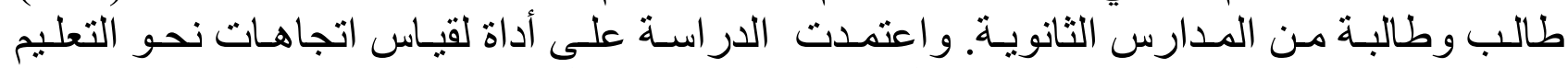

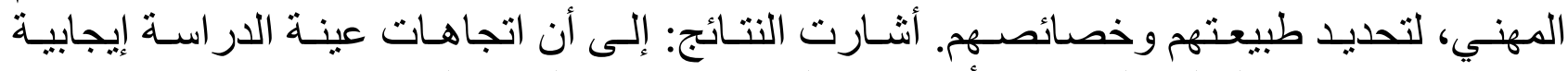

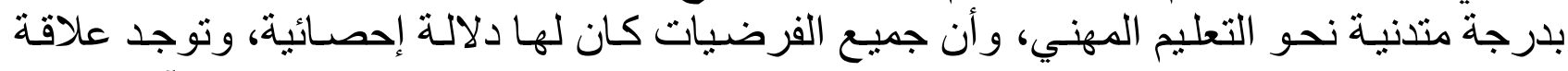

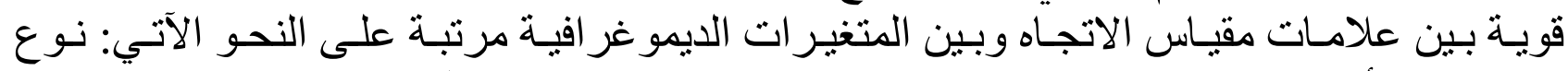

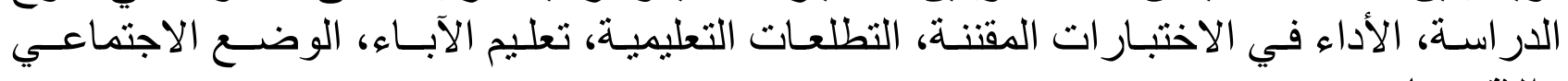
و الاقتصـادي.

أما اريديا (Iredia, 1986) فهدفت إلى تحديد اتجاهات طلبة المدارس العليا المهنية وغير المهنية في الميات

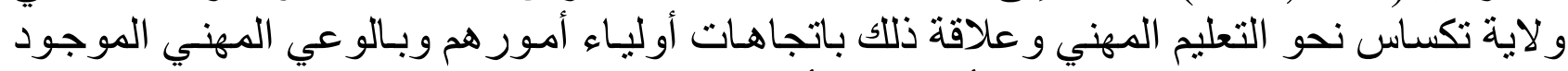

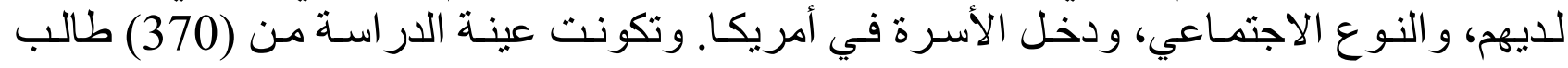

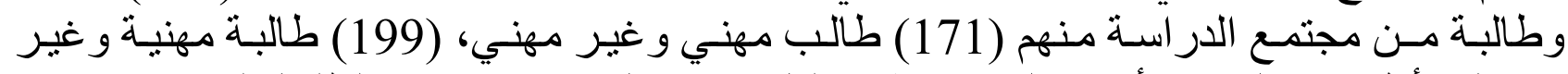

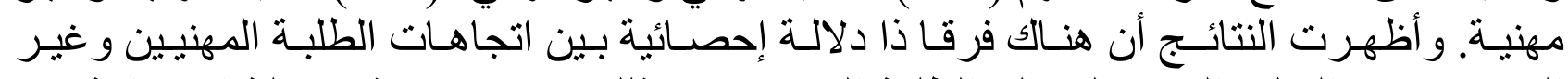

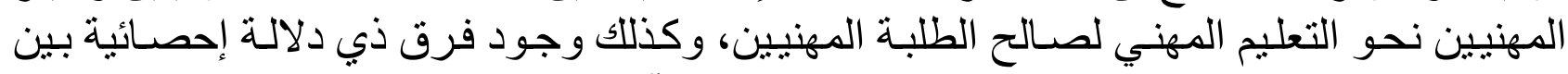

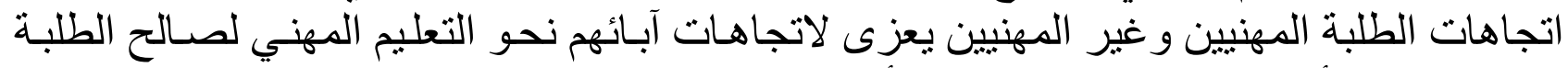

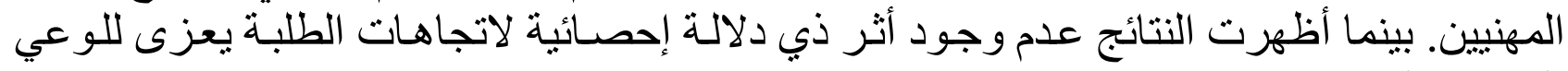
المهني و النوع الاجنماعي.

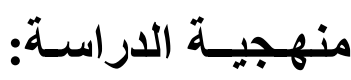

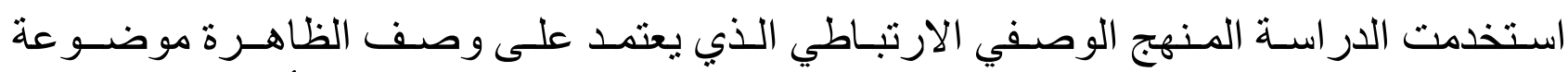

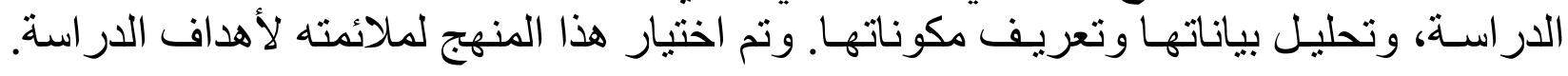

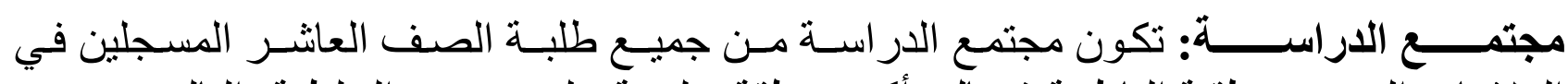

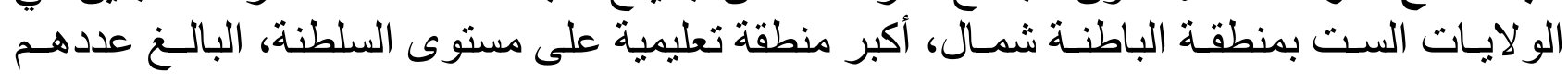




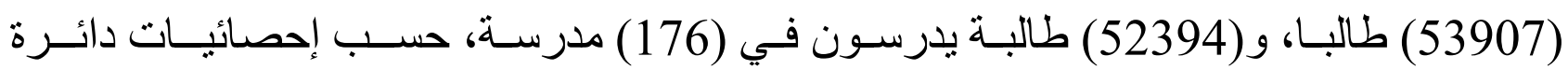
التخطيط و الاحتياجات التعليميـة وضبط طالية الجودة، قسم الإحصـاء و المؤشـر ات.

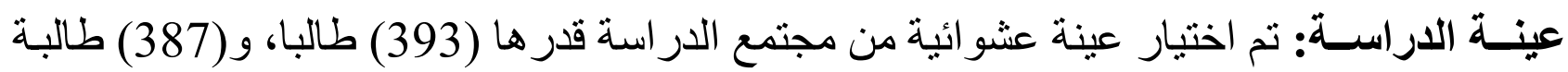

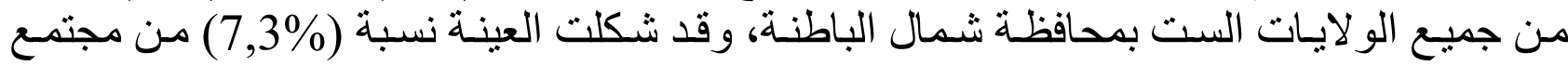
الدر اسة حمن أدوات الدراسـة: تتكون أدوات الدر اسة من ثلاث مقاييس: 1. مقياس الاتجاه نحو التعليم المهني

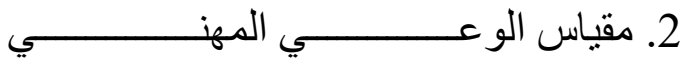
3. 3قياس الاهتمامات المهنية

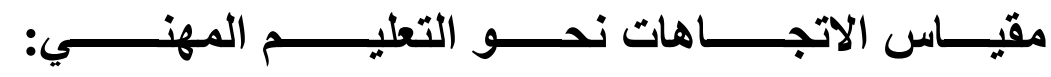

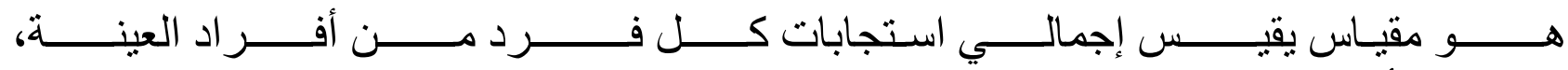

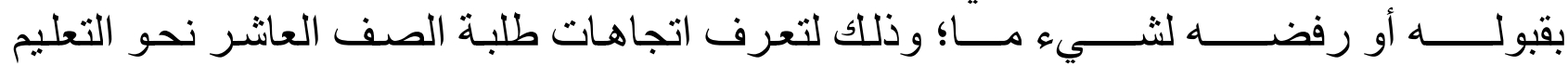

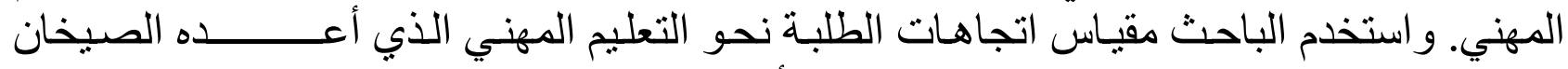

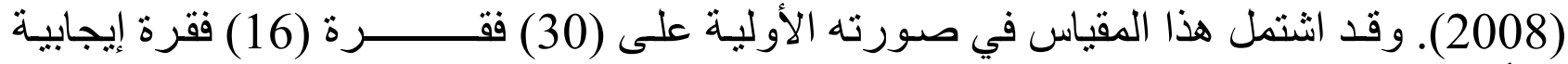

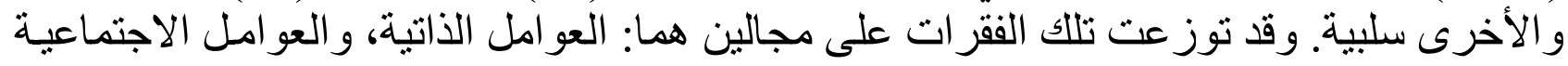

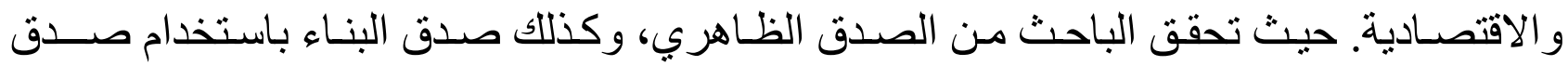

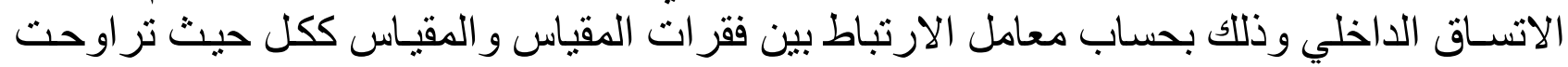

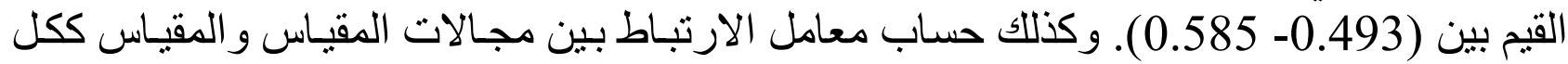

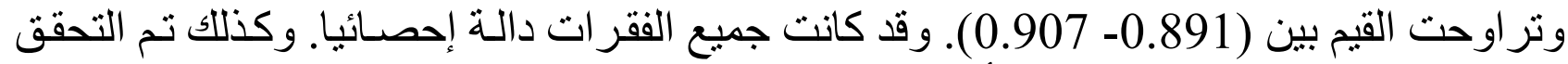

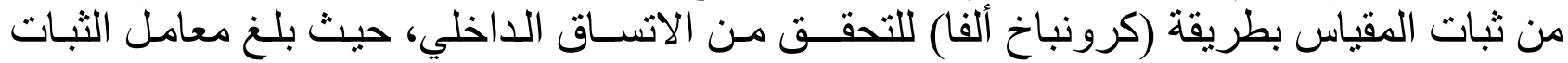

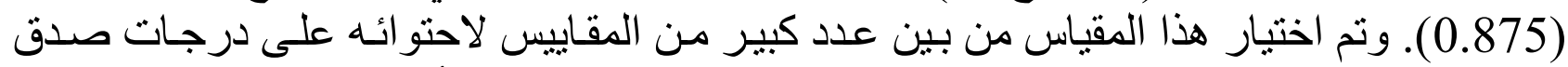

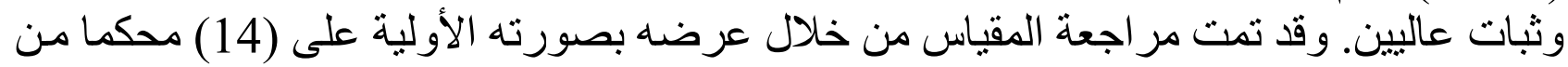

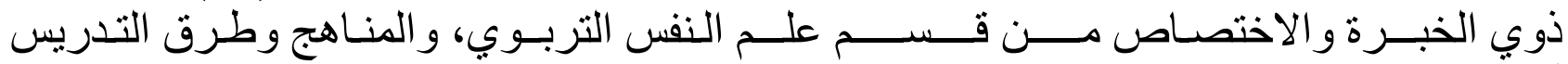

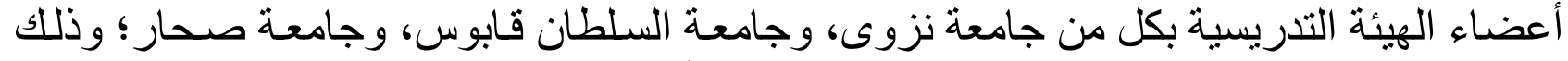

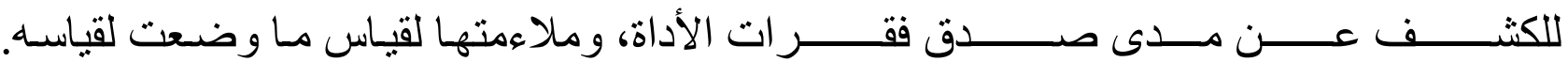

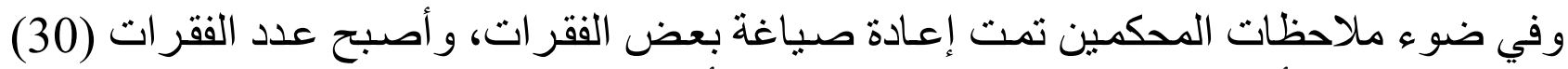
فقرة. بذللك تكون أعلى درجة للقياس (150) درجة، و أدنى درجة للقياس (30) درجة.

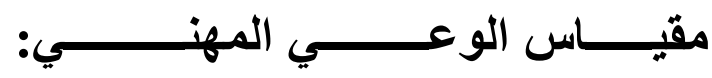

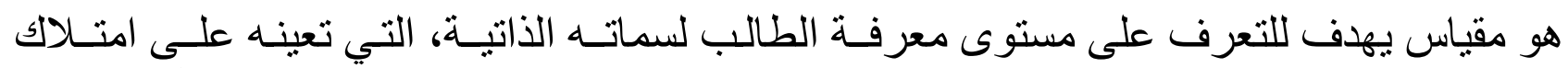

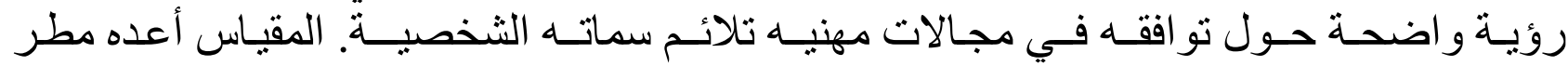

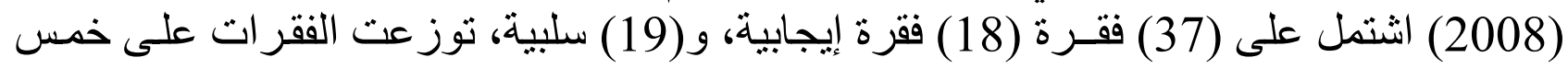

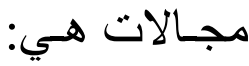
أ. الميـول و القدر ات و القيم ومر اعاتهـا في اتخـاذ القرار، الأ

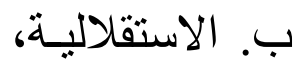




$$
\begin{aligned}
& \text { ت. الاهتمـام، }
\end{aligned}
$$

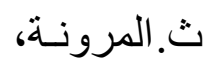

$$
\begin{aligned}
& \text { ج. الاتجــاه نحـو العمل بشـكل عـام. } \\
& \text { ثبـــات المقياس: }
\end{aligned}
$$

تم التحقق من الصدق الظاهري، وقد تمـت مر اجعة المقيـاس من خـلال عرضـهـ على (14) محكمـا

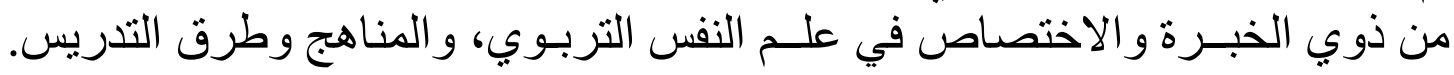

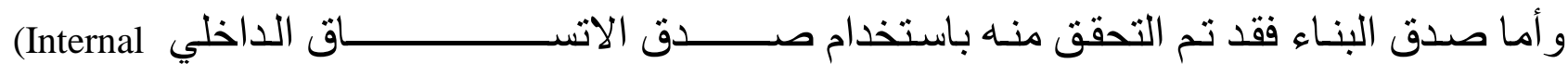
Consistency Validity)

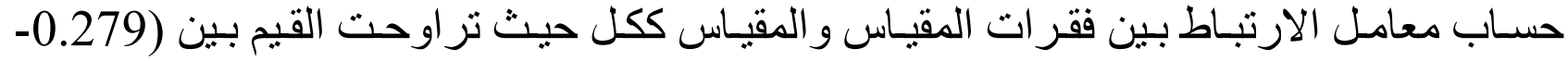
0.634). وكذللك حساب معامل الارتباط بين مجالات المقياس و المقياس ككل وتر اوحت القيم بين

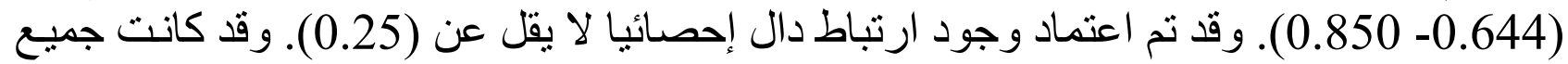
الفقر ات دالة إحصائيا.

كذللك تم التحقق من ثبات المقياس بطريقة (كرونبـاخ ألفـا- Cronbach Alpha) للتحقــق مـن معامـل

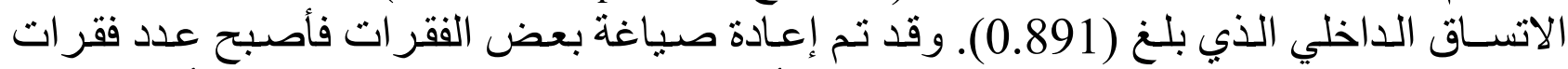
المقياس بصورته النهائية (33) فقرة، بذلك تكون أعلى درجة للقيـاس (165) (16) درجـة، و أدنى درجة للقياس (30) درجة.

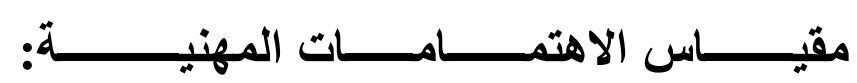

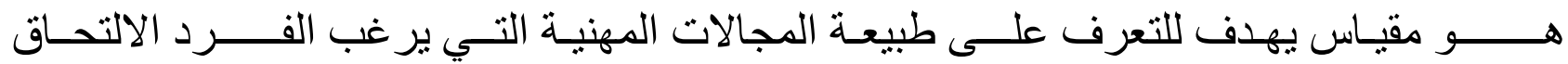

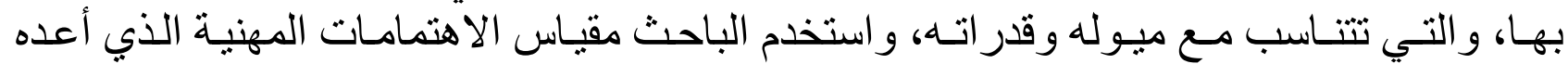

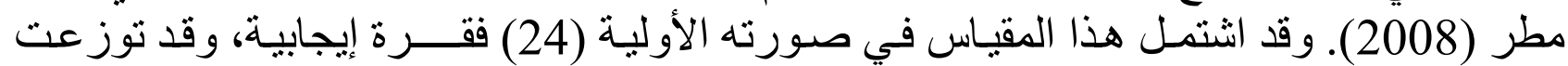

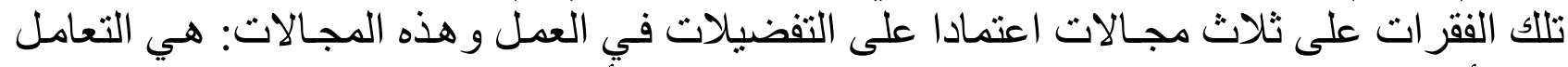

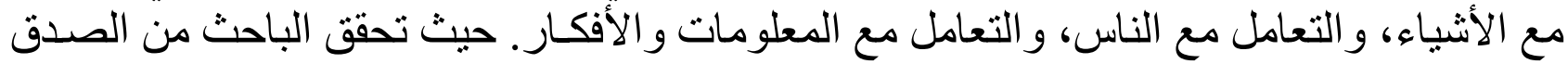
الظاهري، وكذلك صـدق البنـاء باستخدام صدق الاتســاق الداخلي وذلك بحسـاب معامل الارتباط بين فقر ات المقياس و المقيـاس ككل حيث تر اوحت القيم بين (0.438- 0.598) وقد كانت جميع الفقر ات دالة إحصائيا. وكذللك تم التحقق من ثبات المقياس بطريقة (كرونباخ ألفا Cronbach Alpha)

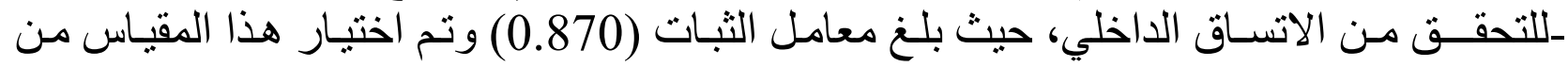
بين عدد كبير من المقاييس لاحتو ائه على درجات صدق وثنبات عاليين. وقد تمـت مر اجعـة المقياس

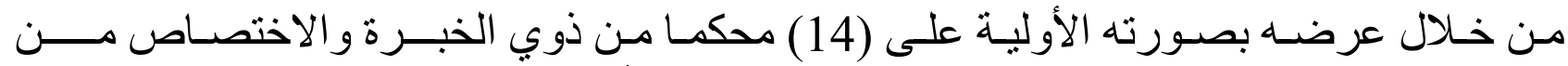

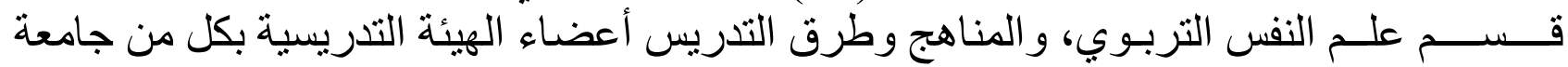

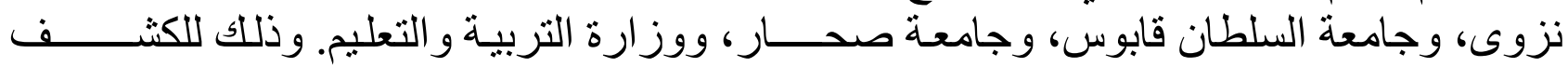

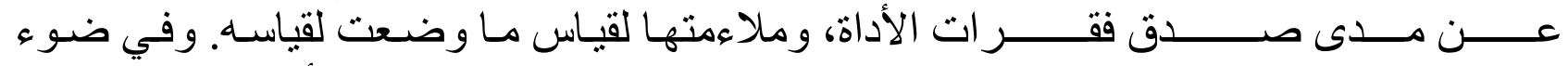

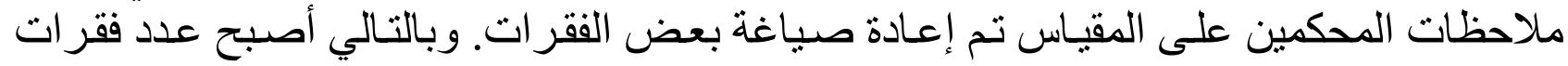
المقياس بصورته النهائية (24) فقرة.

صدق المقياس: للتحقق مـن صدق المقيـاس استخدم الباحثث الصـدق الظـاهري وذلك من خـلال عرضـه بصـورته 


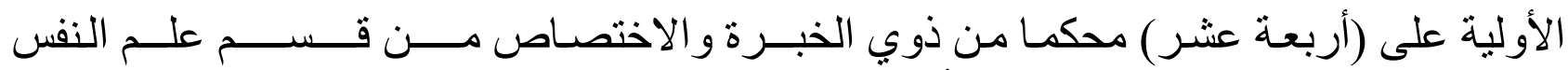

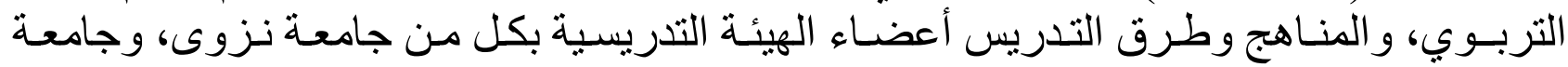

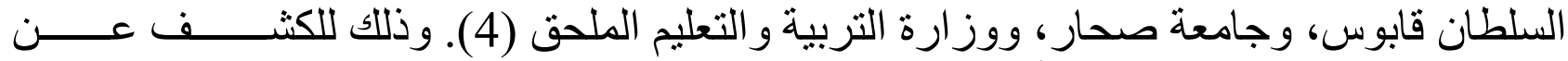

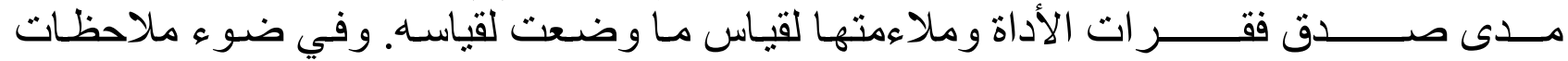

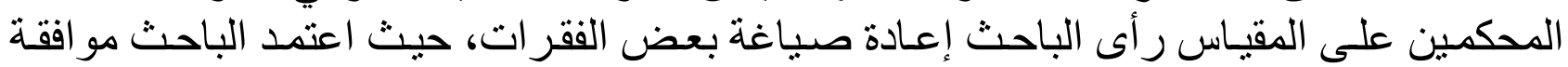

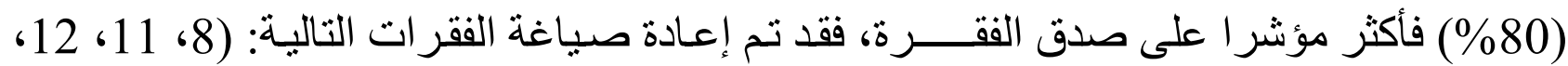

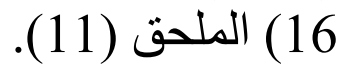

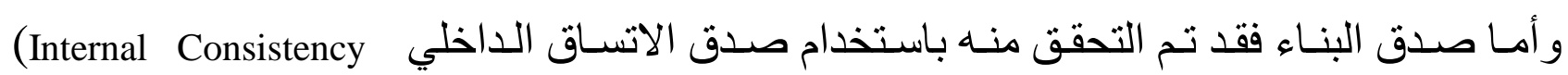

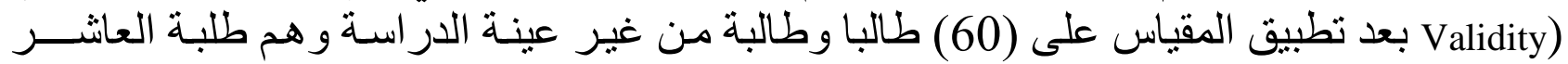

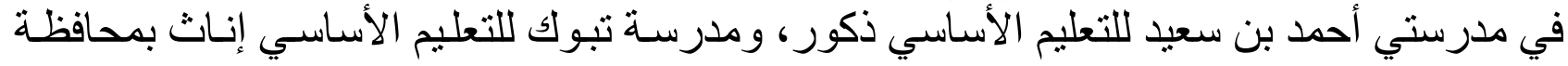

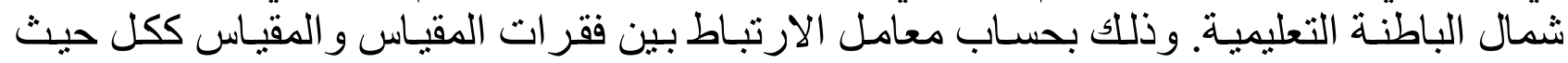

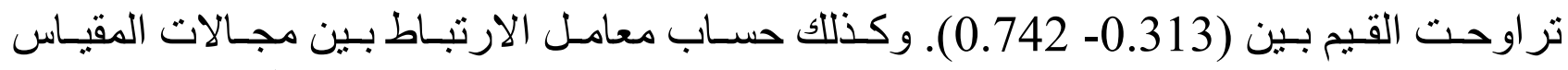
و المقياس ككل وتر اوحت القيم بين (0.810- 0.904). وقات وقد تم اعتماد وجود ارتباط دال إحصـائيا لا يقل عن (0.25). وقد كانت جميع الفقر ات دالة إحصائيا.

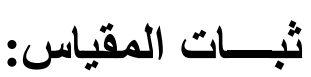

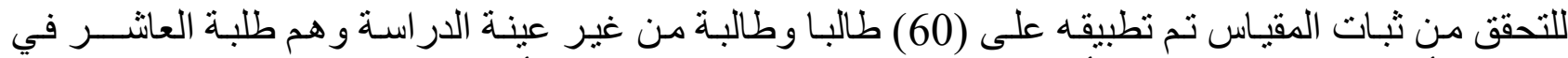

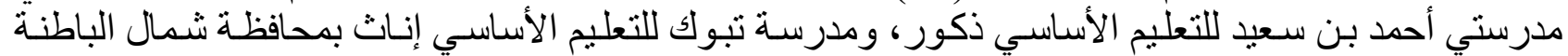

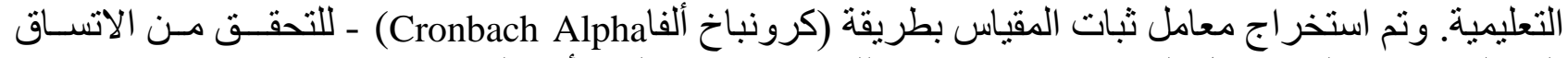

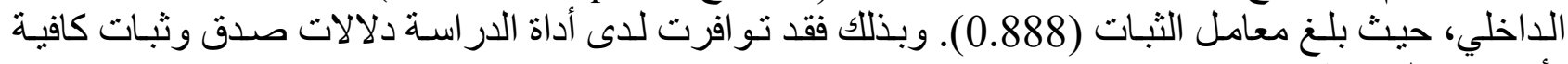

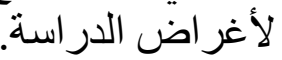

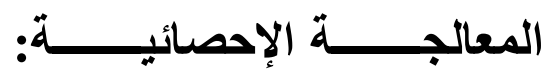

اسـخدمت الدر اسـة في تحليـل البيانـات برنـامج الحزمـة الإحصائيـة للعلـوم الاجتماعيـة (SPSS)

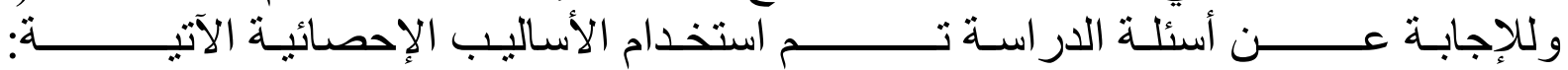
أ. للإجابـة عـن سؤال الدراسة الأول استخدم الإحصـاء الوصفي الوســــ الحســابي والانحر اف

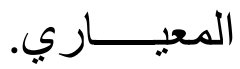

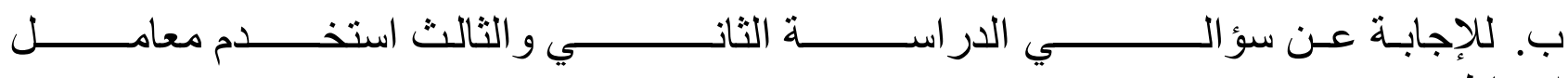

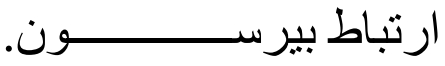

ت. للإجابـة عـن سؤال الدر اسـة الرابـع استخدم اختبار (t) للمقارنة بين الذكـور والإناث. نتائسج الدراسة: نتائـــج الســؤال الأول: ما مستوى اتجاهـات طلبـة الصـف العاثـر في محافظة شمال الباطنـة نحو التعليم المهني؟ تمــت الإجابـة علـى هـذا الســؤال باسـتخدام الإحصــاء الوصـفي، لإيجـاد المتوسـطات الحسـابية

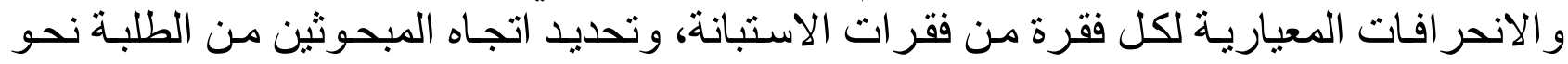

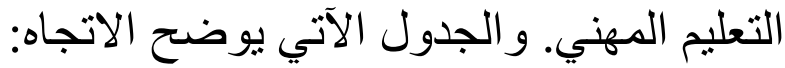


جدول () المتوسطات الحسابية و الانحر افات المعيارية و الرتبة حسب تقدير ات العينة

لفقرات أداة الاتجاه كاملة مرتبة تتاز ليا

\begin{tabular}{|c|c|c|c|c|c|}
\hline الترتيب & النسبي & الانحر افعياري & الحسطي & ـــــرات & الفقرة - مقة \\
\hline 1 & .826 & 0.853 & 4.132 & 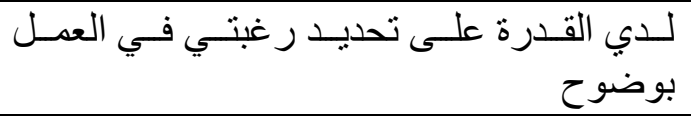 & 1 \\
\hline 2 & .797 & 1.144 & 3.988 & 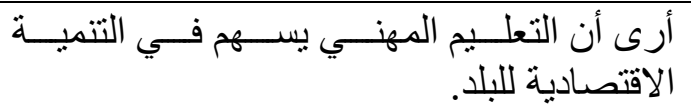 & 29 \\
\hline 3 & .795 & 1.100 & 3.978 & أبقثق أن التعليم المهني يساعد في تخفيف مشكلة & 27 \\
\hline 4 & .783 & 1.153 & 3.919 & 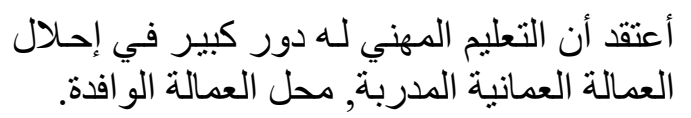 & 24 \\
\hline 5 & .779 & 1.075 & 3.896 & أرغب في الالتحاق بالتعليم المهني لأنه يتيح لي & 2 \\
\hline 6 & .751 & 1.114 & 3.755 & 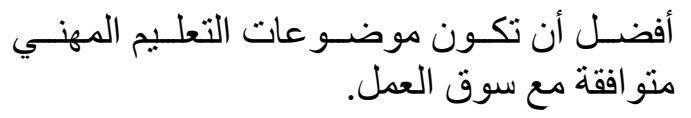 & 19 \\
\hline 7 & .747 & 1.146 & 3.738 & 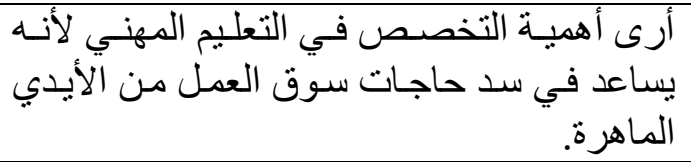 & 23 \\
\hline 8 & .745 & 1.107 & 3.729 & خاصطة لدى الفرد. التعليم المهني مهار ات وقدر ات & 9 \\
\hline 9 & .744 & 1.112 & 3.724 & أعتقدا بأن العمل المهني يتو افق مـع واقع الحياة & 13 \\
\hline 10 & .676 & 1.066 & 3.383 & مناسب. أفــل العهـل المهنــي لأن مــردوده المــــي & 3 \\
\hline 11 & .674 & 1.204 & 3.370 & أرى بأن وسائل الإعلام لا تعطينا الوعي الكافي & 17 \\
\hline 12 & .665 & 1.208 & 3.328 & 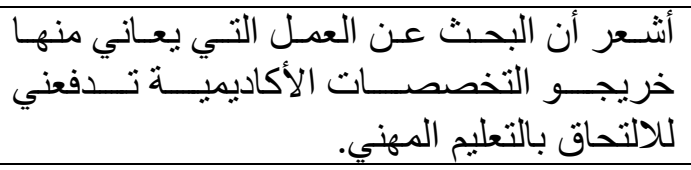 & 26 \\
\hline 13 & .660 & 1.437 & 3.300 & أطالتقات أن التعليم المهني مناسب للطلاب أكثر من & 15 \\
\hline 14 & .654 & 1.352 & 3.274 & 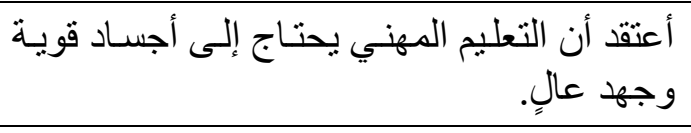 & 10 \\
\hline 15 & .653 & 1.407 & 3.265 & أعتقـــ أن التعلـيم المهنــي يناسـبـ الطلبـــة غيـر & 25 \\
\hline 16 & .648 & 1.285 & 3.242 & 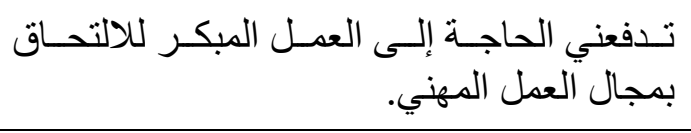 & 7 \\
\hline
\end{tabular}


IJASOS- International E-Journal of Advances in Social Sciences, Vol. VI, Issue 16, April 2020

\begin{tabular}{|c|c|c|c|c|c|}
\hline 17 & .645 & 1.352 & 3.226 & 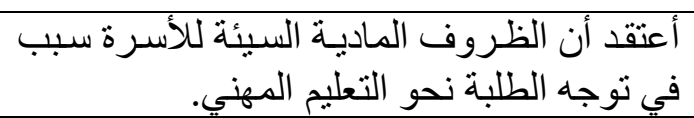 & 30 \\
\hline 18 & .642 & 1.387 & 3.212 & أفضل الالتحـاق بـالتعليم المهني حتى ولو كنـت & 11 \\
\hline 19 & .626 & 1.395 & 3.130 & أرىى بأن المدرسة لا تعطينا معلومات كافية عن & 8 \\
\hline 20 & .621 & 1.207 & 3.105 & متدنية. أعتقد أنظرة المجتمع إلى طلبة التعليم المهني & 20 \\
\hline 21 & .619 & 1.250 & 3.096 & عليه. جلي بنو عيـة الأعمـال المهنية يقلل من إقبالي & 22 \\
\hline 22 & .611 & 1.380 & 3.056 & 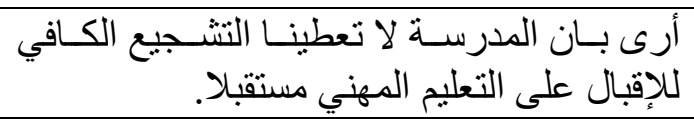 & 14 \\
\hline 23 & .585 & 1.225 & 2.929 & المجنمع المبندنية له اختيـاري التعليم المهني نظرة & 28 \\
\hline 24 & .565 & 1.234 & 2.825 & ألثــعر أن التعلـيم المهنـي مرهـق و غيـر ملانـم & 16 \\
\hline 25 & .552 & 1.222 & 2.761 & الجامعية. المهني لا تمكنتي من مو اصلية در استتي & 4 \\
\hline 26 & .554 & 1.290 & 2.723 & المستقبل. من العمل المهني يقلل من إقبالي عليه في & 5 \\
\hline 27 & .542 & 1.209 & 2.711 & متقدم. التعليم المهني لا يوصلني إلى مركز اجتمـاعي & 12 \\
\hline 28 & .533 & 1.310 & 2.669 & أشتعر أن مهنـة و الـدى تـؤثر في تـوجهي نحسو & 18 \\
\hline 29 & .527 & 1.206 & 2.639 & إقبالي عليه اختيـار زملانسي للتعلـيم المهنـي يقلل مـن & 6 \\
\hline \multirow[t]{2}{*}{30} & .514 & 1.314 & 2.570 & المهني تمنعي ضـغوط الأهل مـن الاتجـاه نحو التعليم & 21 \\
\hline & 0.657 & 0.377 & 3.289 & المجموع & \\
\hline
\end{tabular}

يتضـح من الجدول أعلاه، بأن معدل المتوسط الحسابـــي لجميع فقرات ات أداة الدر اســــــة (3.289)

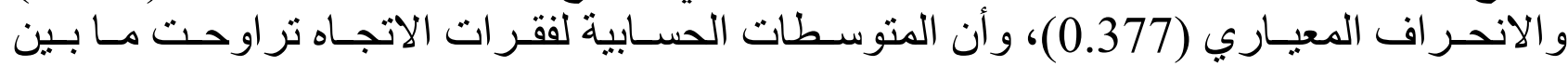

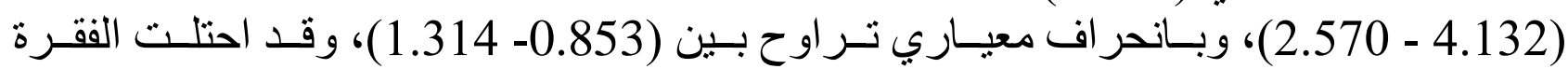

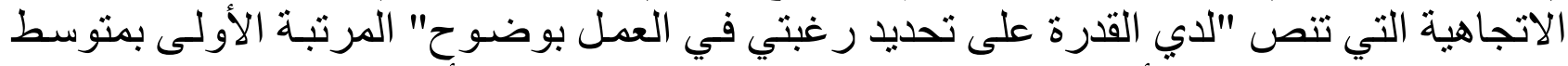

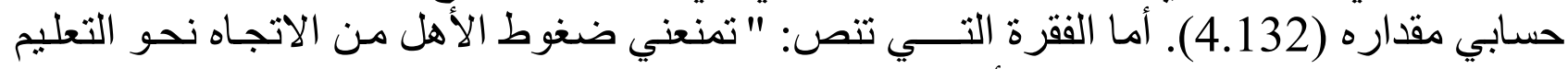
المهني" فقد حصلت على المرنبة الأخيرة وبمنوسط حسابي وقدره (لفي (2.570). 


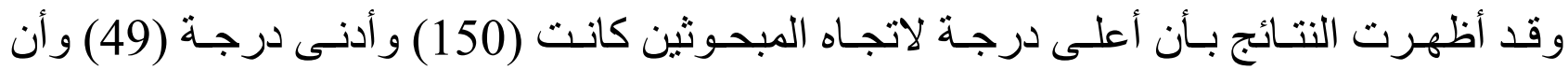

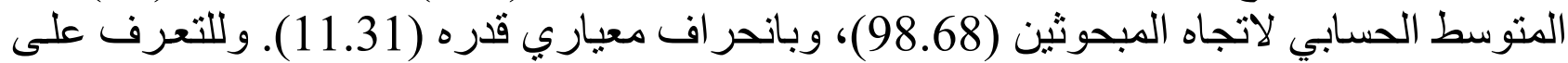

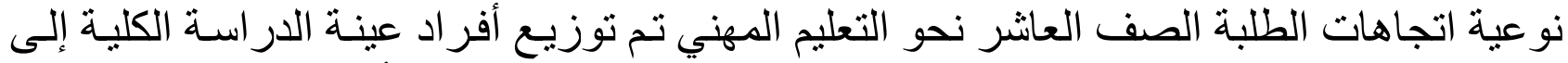

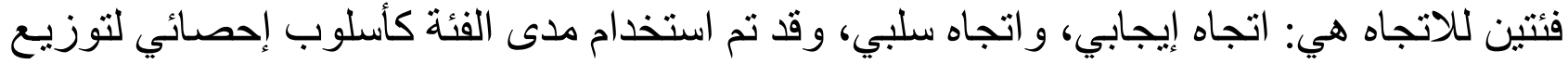

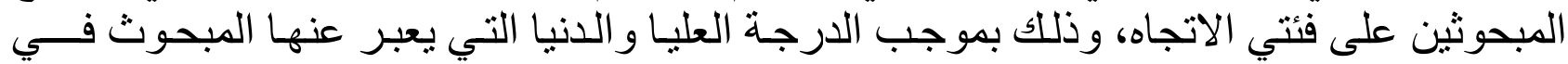

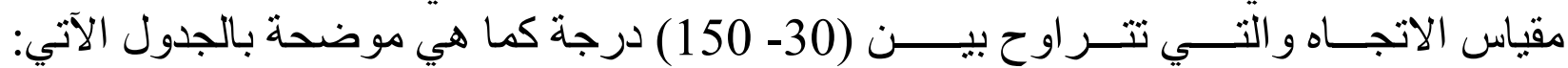

جدول( 5 ) الأعداد و النسب المئوية للمبحوثين من طلبة الصف العاشر موزعين وفقا

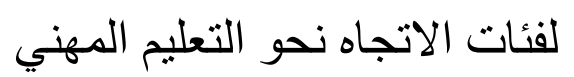

\begin{tabular}{|c|c|c|}
\hline$\%$ & عدد الطلبة & فئات الاتجاه \\
\hline 23.1 & 180 & اتجاه سلب. بـــي (30 - 90) \\
\hline 76.9 & 600 & اتجاه إيجابـــي (91 - 150) \\
\hline 100 & 780 & 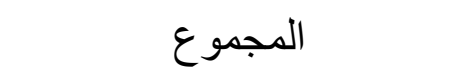 \\
\hline
\end{tabular}

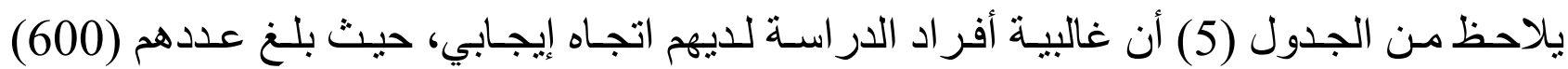

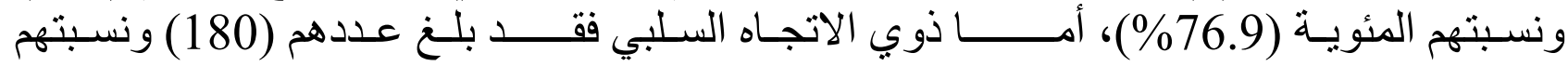
المئوية (23.1\%).

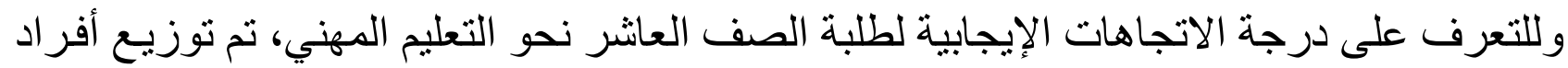

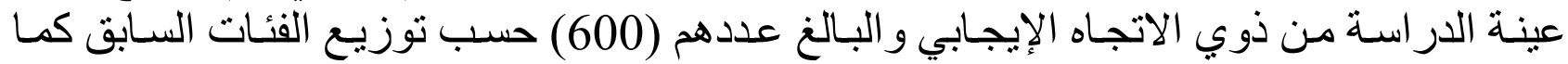

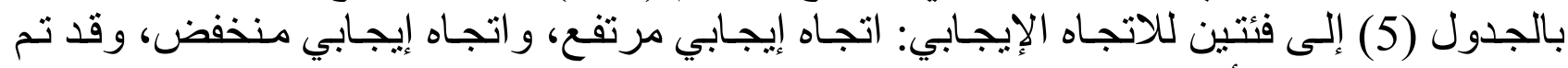

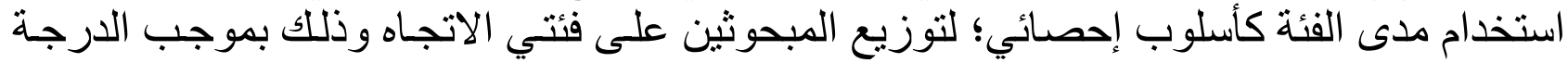

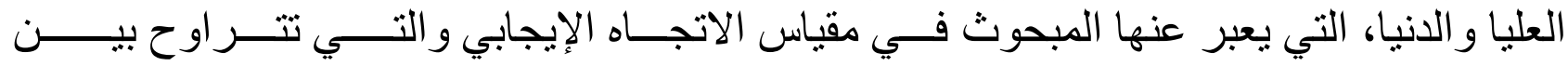
(150-91) درجة كما هي موضحة بالجدولَّل الآتي:

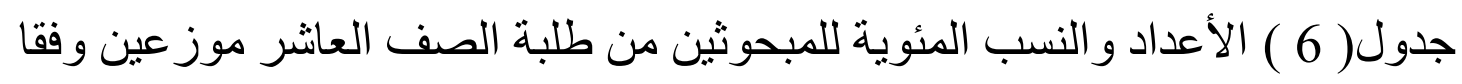
لفئات الاتجاه الإيجابي نحو التعليم المهني

\begin{tabular}{|c|c|c|}
\hline$\%$ & عدد الطلبة & فئات الاتجاه \\
\hline 96.8 & 581 & اتجاه إيجابي منخفض (91 - 120) \\
\hline 3.2 & 19 & اتجاه إيجابسي مرتفـــع (121 - 150) \\
\hline
\end{tabular}




\begin{tabular}{|l|l|l|}
\hline 100 & 600 & المجموع \\
\hline
\end{tabular}

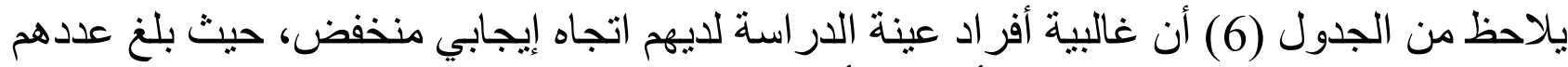

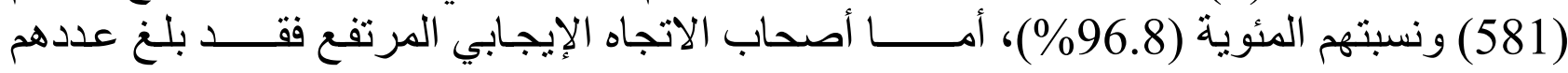

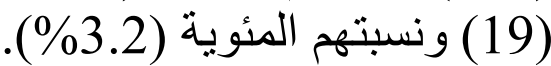

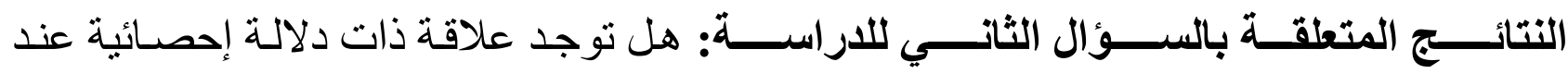
مستوى (0.05) بين اتجاهات الطلبة في عينة الدراسة نحو التعليم المهني وو عيهم المهني؟ لأني

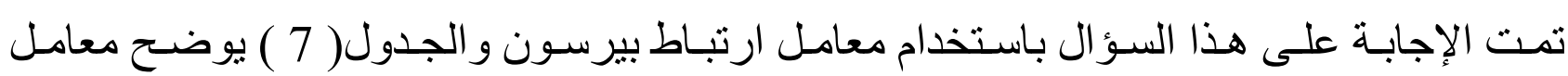

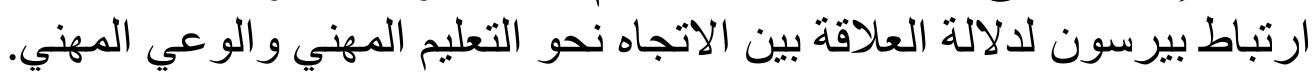
جدول ( 7 ) معامل ارتباط بيرسون لدلالة العلاقة بين الاتجاه نحو التعليم المهني والوعي المهني

\begin{tabular}{|c|c|c|c|}
\hline الالالة الإحصائية & 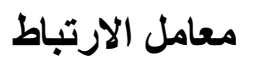 & المجـــــــال & p \\
\hline دالة عند 0.01 & $0.294 * *$ & الميول و القدر ات ومر اعاتها في اتخاذ القرار & 1 \\
\hline دالة عند 0.01 & $0.413 * *$ & الاستقلالية & 2 \\
\hline دالة عند 0.01 & $0.400 * *$ & 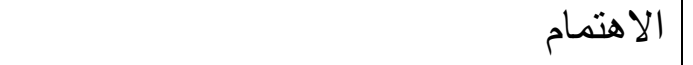 & 3 \\
\hline دالة عند 0.01 & $0.404 * *$ & | لمرونة المرو & 4 \\
\hline دالة عند 0.01 & $0.415 * *$ & الاتجاه نحو العمل بشكل عام & 5 \\
\hline دالة عند 0.01 & $0.584 * *$ & \multicolumn{2}{|l|}{ 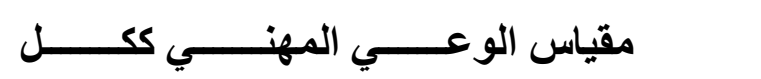 } \\
\hline \multicolumn{2}{|c|}{ * مستوى الدلالة عند 0.05} & \multicolumn{2}{|c|}{ * مستوى الدلالة عند 0.01} \\
\hline
\end{tabular}

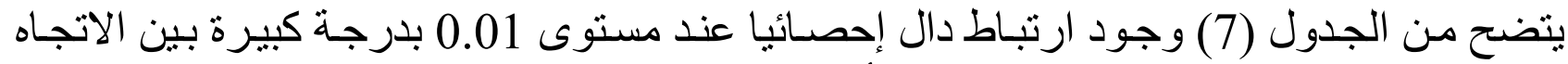

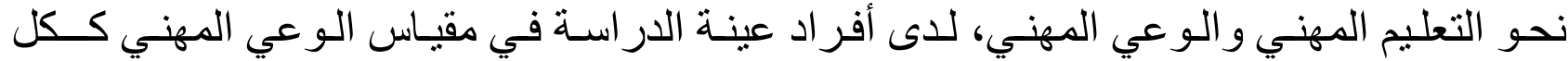

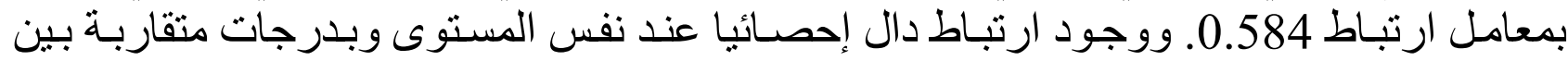

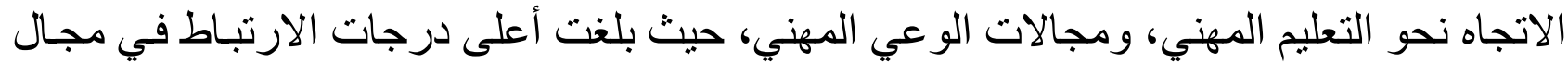

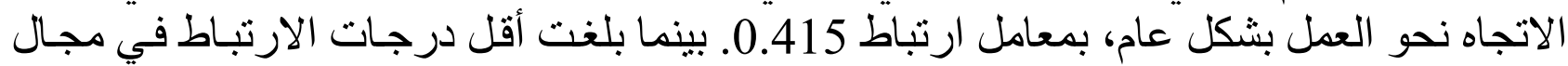

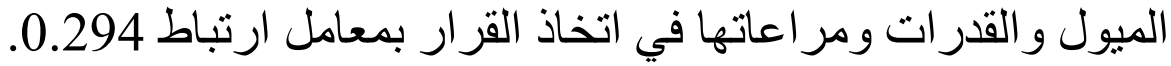

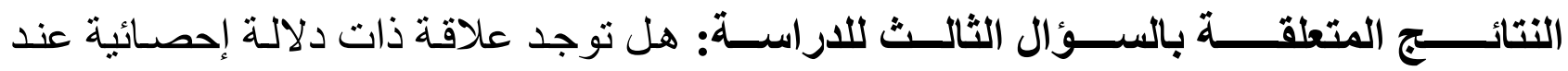

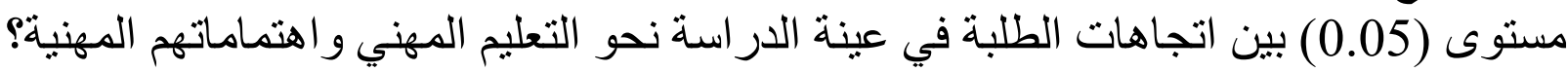

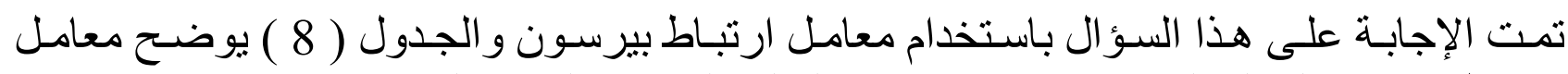

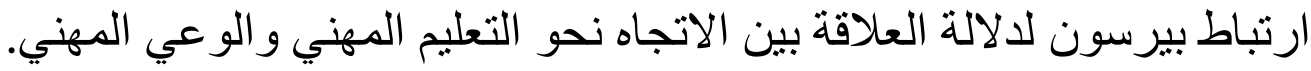


جدول ( 8 ) معامل ارنباط بيرسون لدلالة العلاقة بين الاتجاه نحو التعليم المهني والاهتمامات المهنية

\begin{tabular}{|c|c|c|c|}
\hline الدلالة الإحصائية & معامل الارتباط & المجـــــال & م \\
\hline دالة عند 0.01 & $0.257 * *$ & التعامل مع الأشياء & 1 \\
\hline دالة عند 0.01 & $0.221 * *$ & التعامل مع الناس & 2 \\
\hline دالة عند 0.01 & $0.228 * *$ & التعامل مع المعلومات و الأفكار & 3 \\
\hline دالة عند 0.01 & $0.293 * *$ & مقياس الاهتمامات المهنية ككل & 4 \\
\hline \multicolumn{2}{|c|}{ * مستوى الدلالة عند 0.05} & \multicolumn{2}{|l|}{ ** مستوى الدلالة عند 0.01} \\
\hline
\end{tabular}

يتضـح مـن الجدول (8) وجود ارتبـاط دال إحصـائيا عند مستوى 0.01 بـين الاتجـاه نحسو التعليم

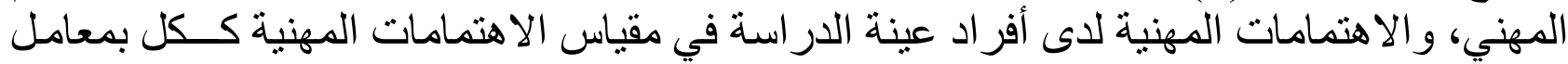

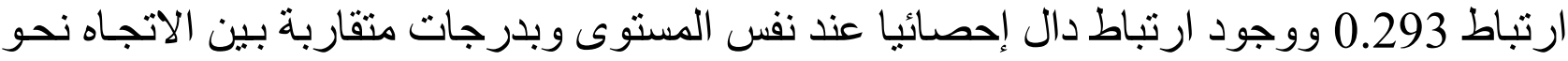

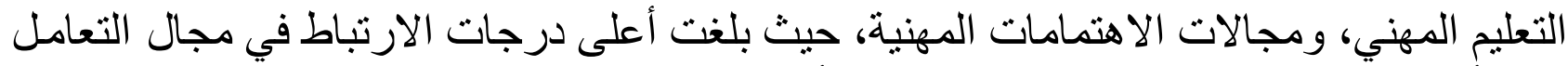

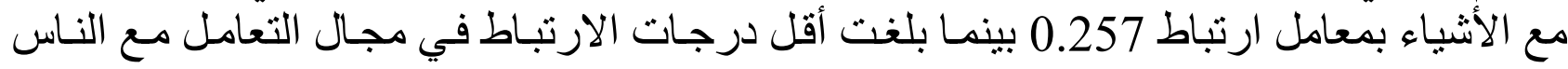
بمعامل ارنباط (0.221).

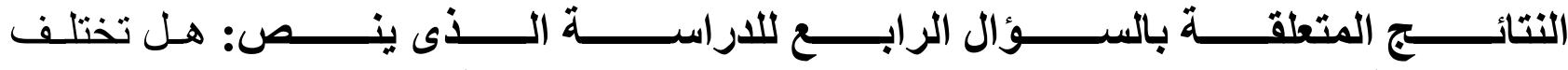
اتجاهات الطلبة في عينة الدراسة نحو التعليم المهني باختلاف نوع الطالب؟

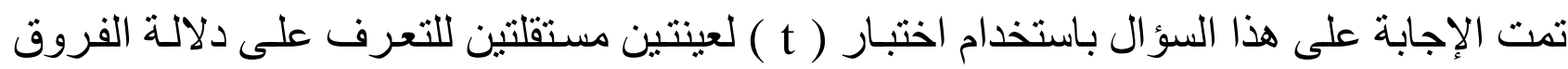

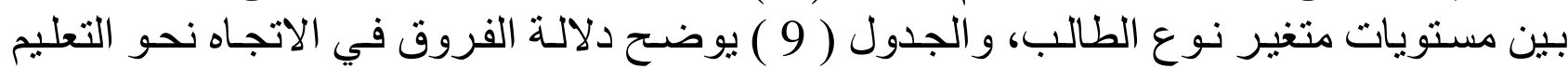
المهني وفقا لمتغير النوع. منغير نوع.

جدول ( 9 ) دلالة الفروق في الاتجاه نحو التعليم المهني وفقا لمتغير النوع

\begin{tabular}{|c|c|c|c|c|c|}
\hline الإحصائية & قيمة (ت) & الانحراف & المتوسط الحسابي & العدد & نوع الطالب \\
\hline \multirow{2}{*}{ غير دالة } & \multirow{2}{*}{0.747} & 0.379 & 3.279 & 393 & ذكر \\
\hline & & 0.360 & 3.299 & 387 & أنتى \\
\hline
\end{tabular}

يتضح من الجدول (9) عدم وجود فروق بين الطلاب و الطالبات في الاتجاه نحو التعليم المهني، 


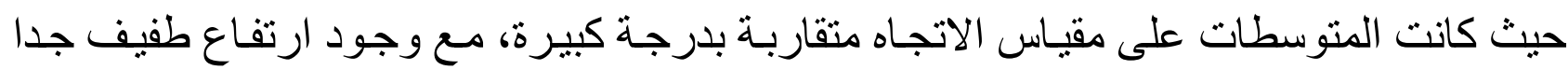

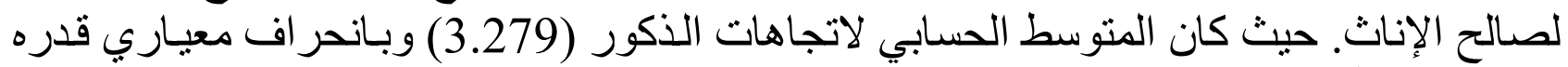

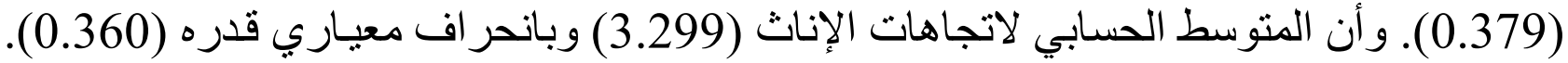

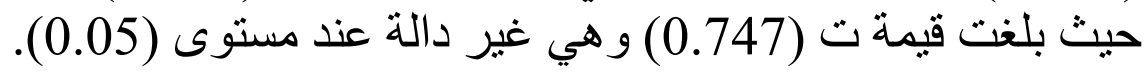

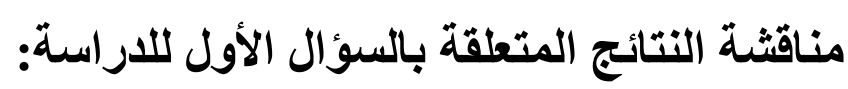

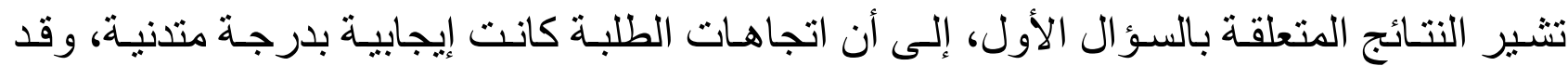

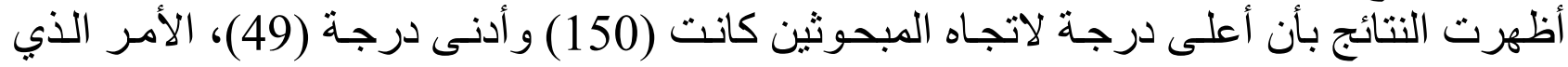

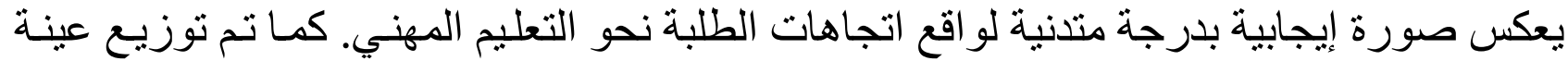

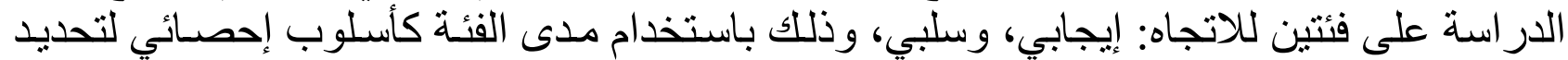

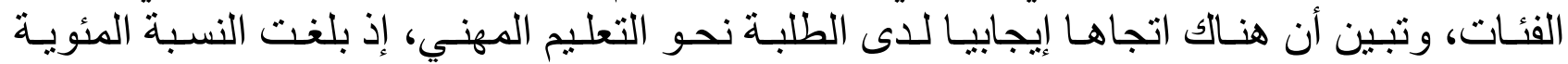

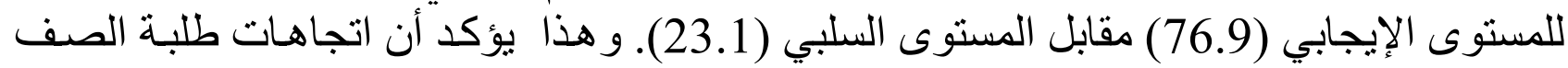
العاثر إيجابية بدرجة متدنية.

تتفق هذه النتيجة مع نتائج الدر اسات التى تناولت اتجاهات طلبة التهات الصف العاثشر نحو التعليم المهني،

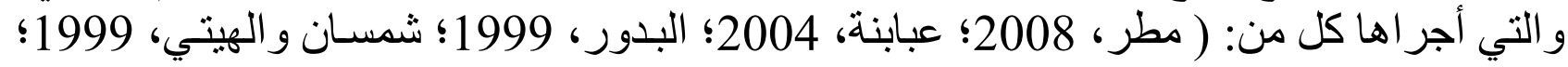

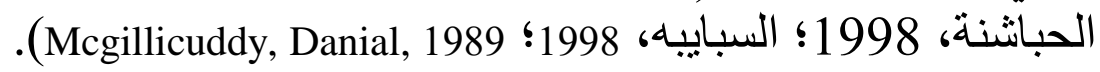

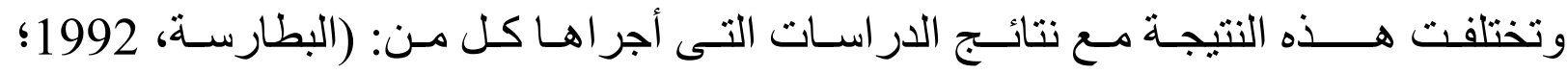

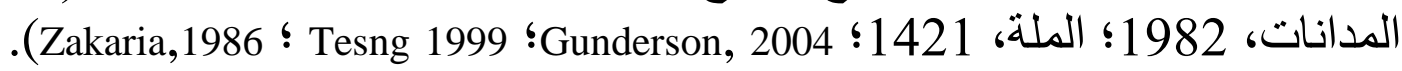

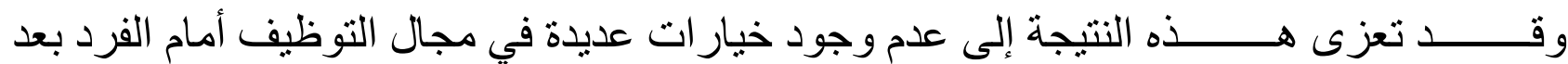

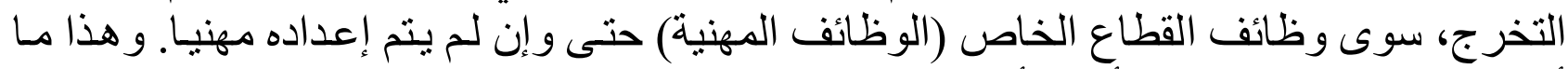

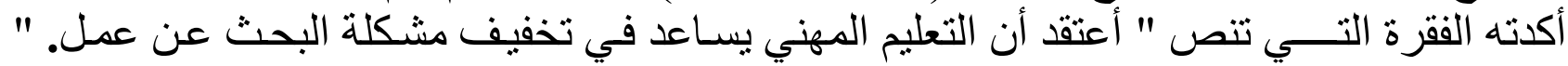

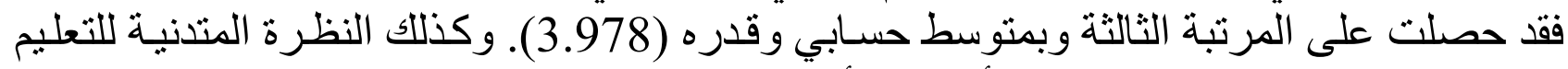

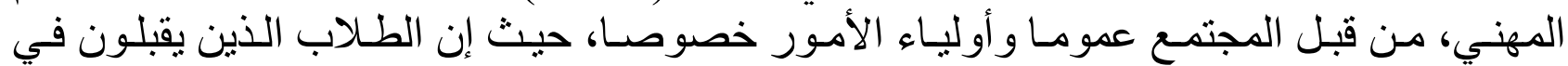

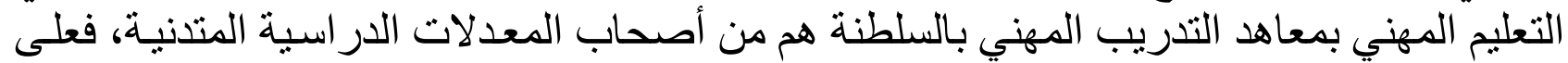

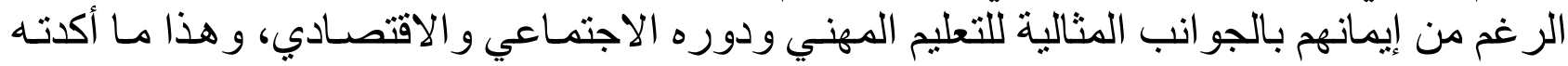

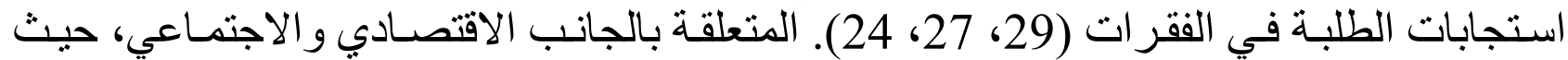

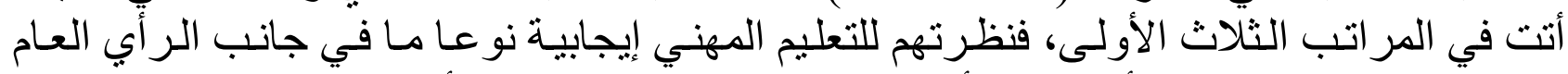

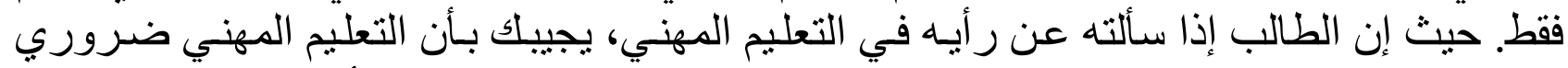

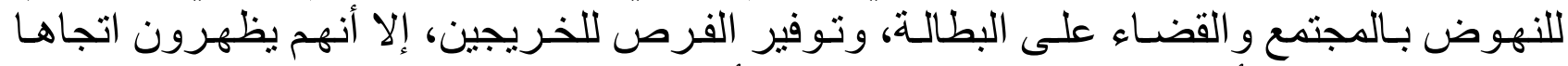

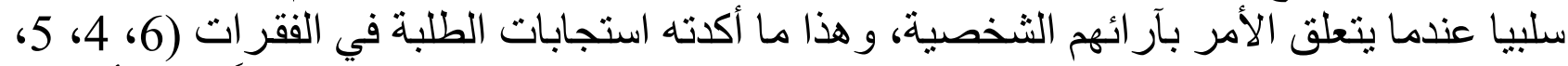

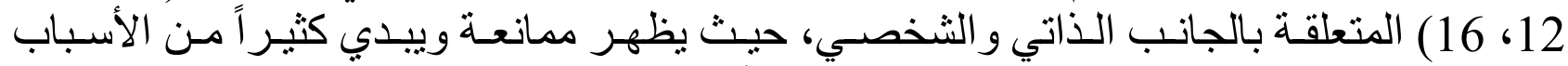
و المبررات عن ذللك كنظرة المجتمع المتندية إليه و لأسرته.

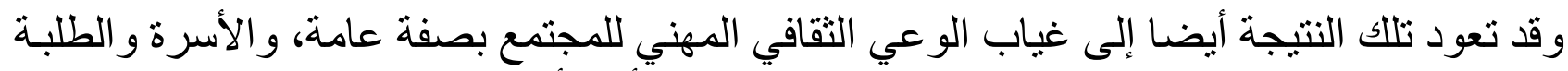

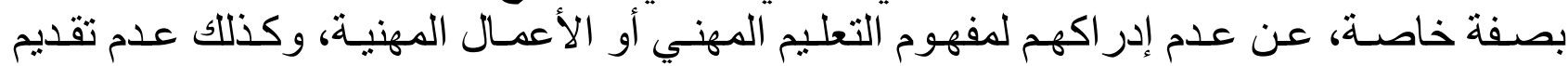

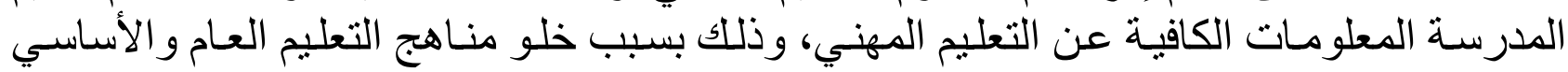

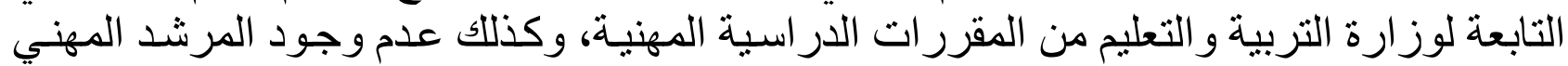


الذى يوجه الطلبة نحو مسار ات التعليم المختلفة بعد دبلوم التعليم العام.

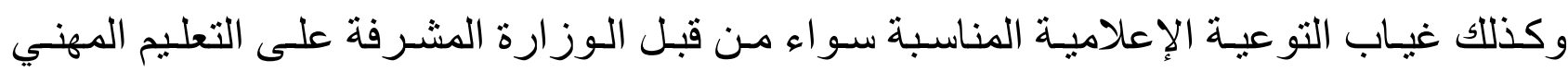

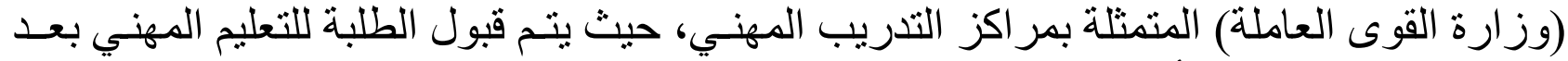

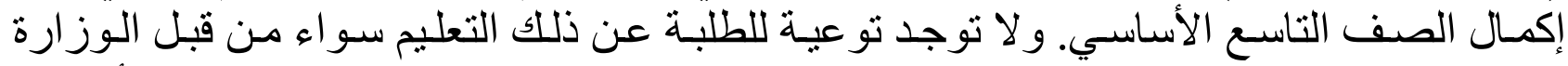

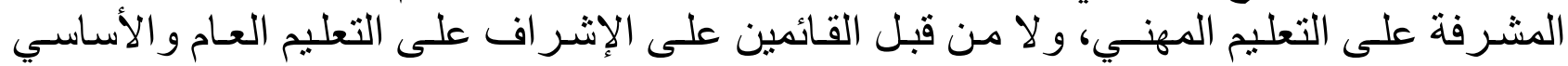

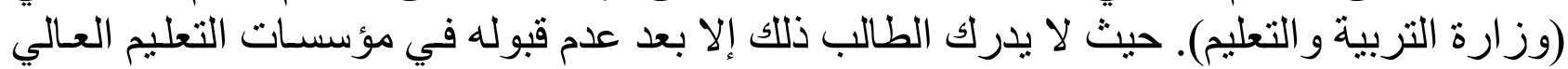

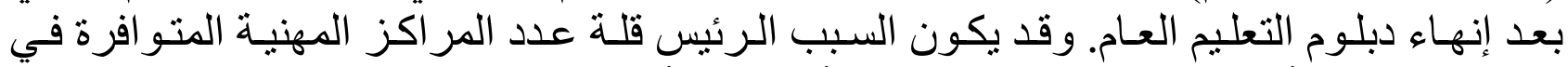

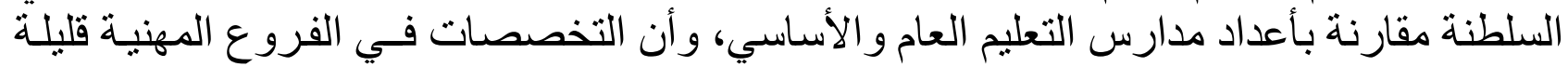

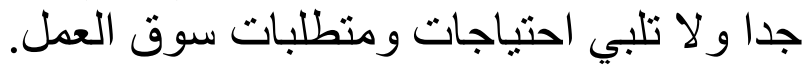
النتائج المتعلقة بالسؤال الثاني للار اسئة: هل توجد علاقة ذات دلالة إحصائية عند مستوى (0.05) بين اتجاهات الطلبـة في عينة الداراسـة نحو التعليم المهني ووعيهم المهني؟

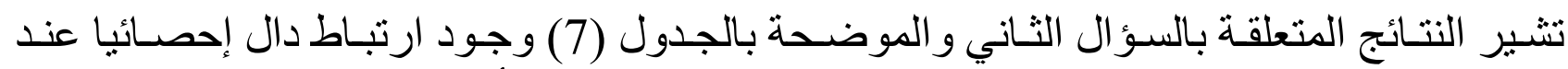

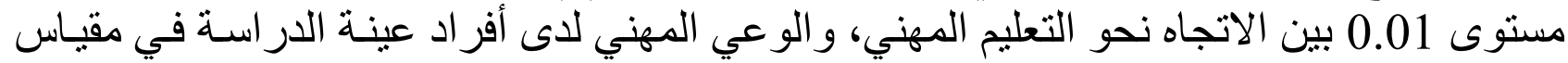

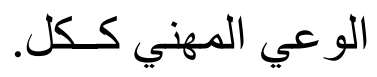

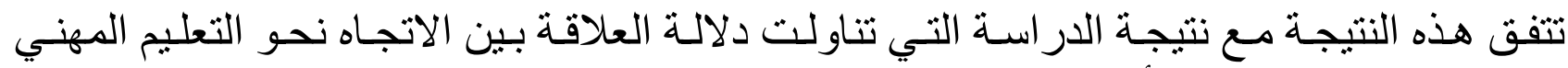

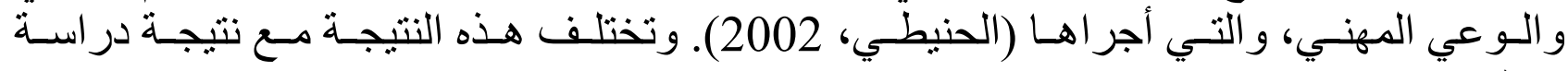

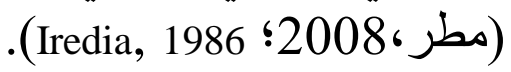

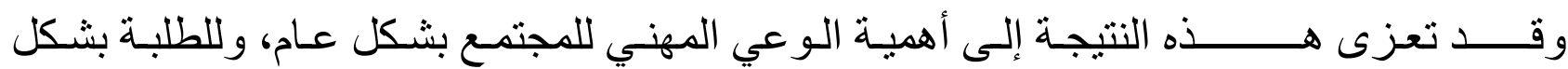

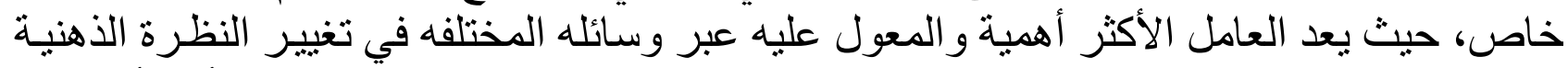

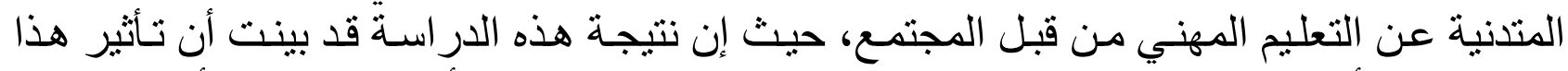

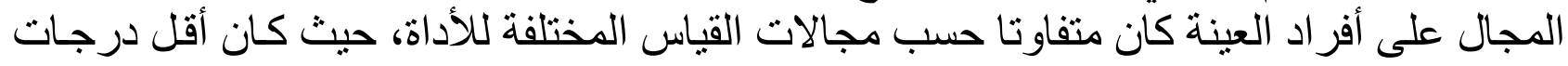

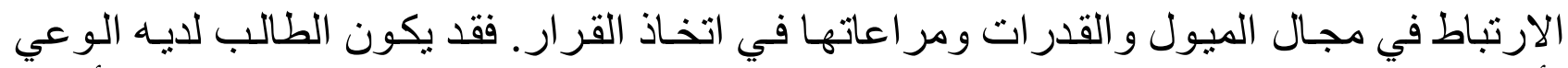

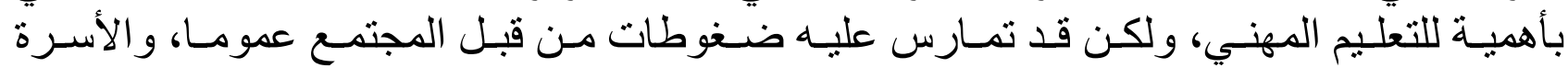

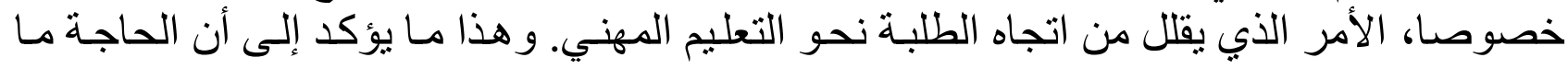

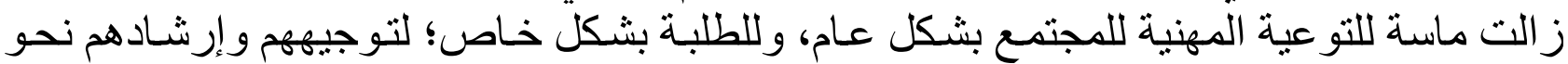

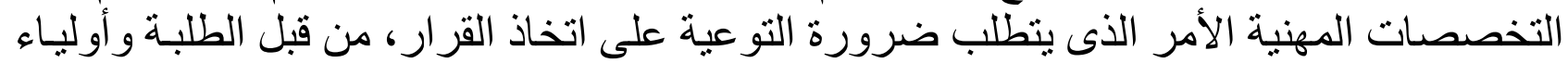

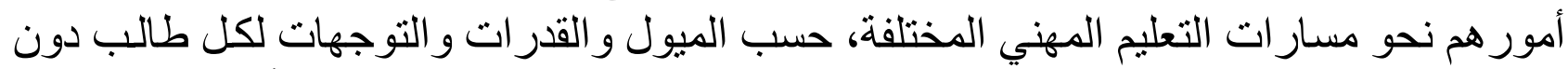

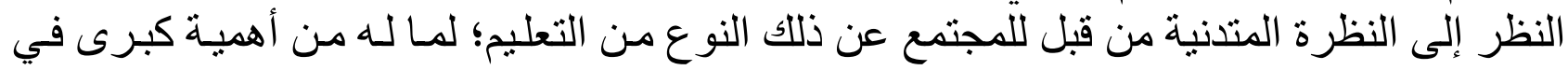

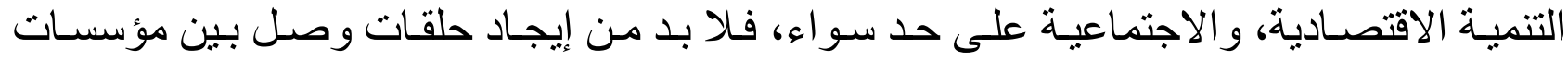

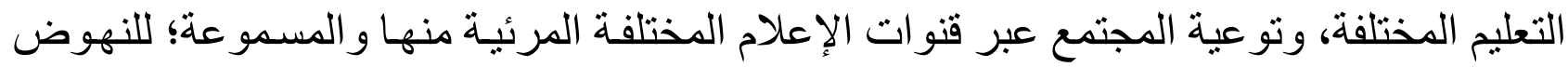

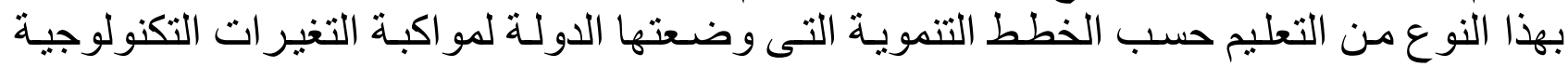

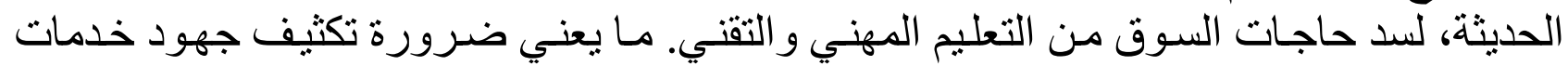

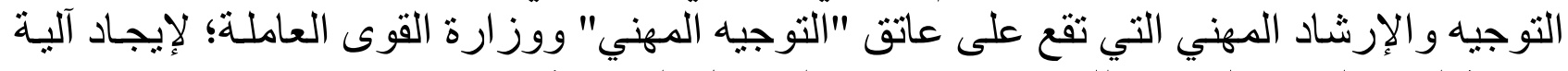

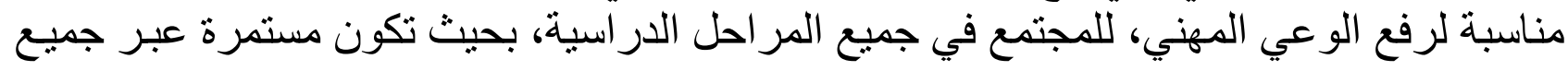


الصفوف الدر اسية، وكذلك التعليم التقني ممثلة في "الكليات التقنية". حيث إن الخدمات المقدمة هي

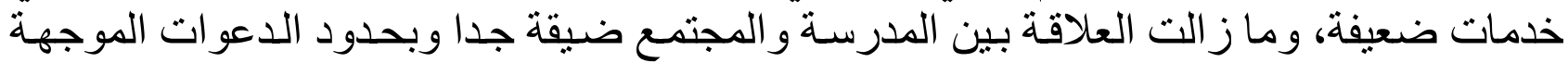
من المدرسة لحضور بعض الفعاليات التربوية.

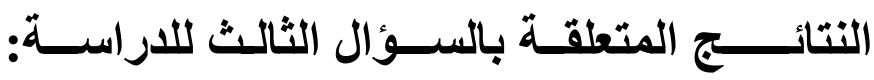

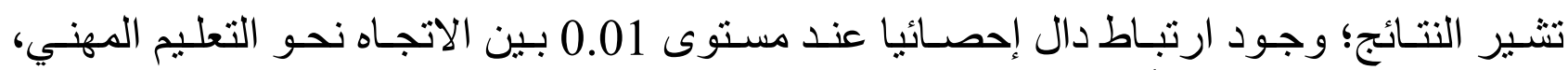

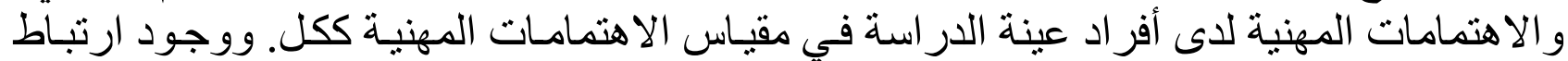

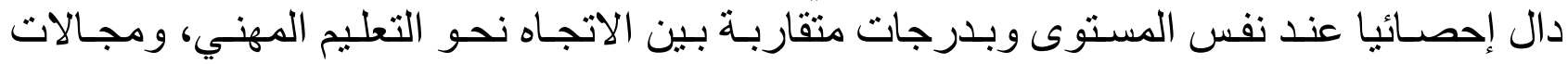
الاهتمامات المهنية.

تتفق هذه النتيجة مـع نتائج الدراسـات التي تناولت دلالـة العلاقـة بين الاتجـاه نحو التعليم المهني و الاهتمامات المهنية، و التي أجر اها كل من ( الحنيطي، 2002؛ قندلفت،

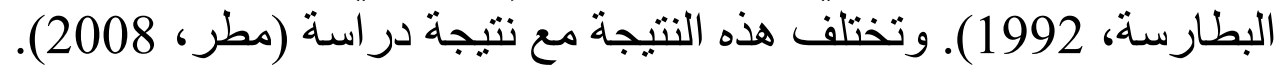

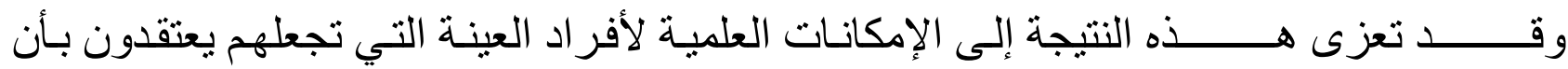
التعليم المهني هو المجال الذي يمكن أن بحققو ا فيه الكثير من الإنجاز ات، التي ير غبون في في تحقيقها

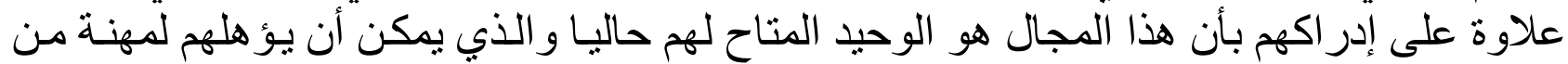

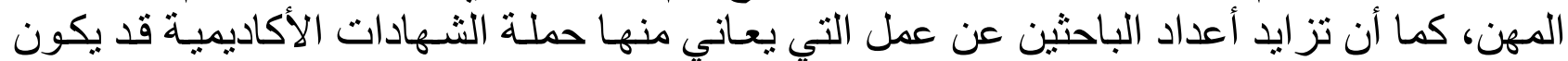
لها أثز في هذه النتائج، وكل ذلك يسـهم بشكل أو بـآخر إلى إعـادة صبياغة طموحساتهم بمـا يتناسـب و الو اقع الذي يتجلى بوضوه هذه في إطار التعليم المهني.

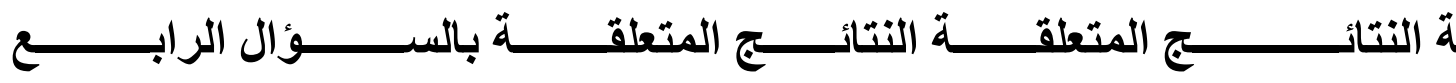

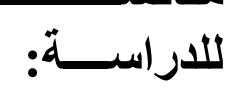

تشير النتائج إلى عدم وجود فروق بين الطلاب و الطالبات في الاتجاه نحو التعليم المهني، مع وجود

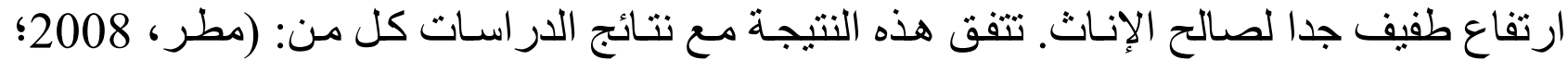
الحباشنة، 1998؛ السبايبة، 1998؛ Iredia,1986). وتختلف مع نتائج در اسات: (الطر اونـة، 2000؛

عبابنه، 2004).

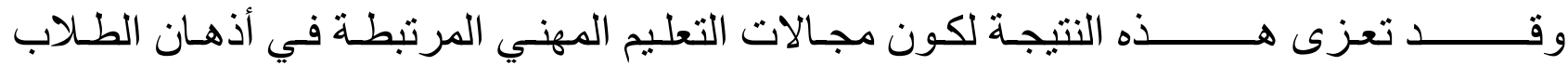

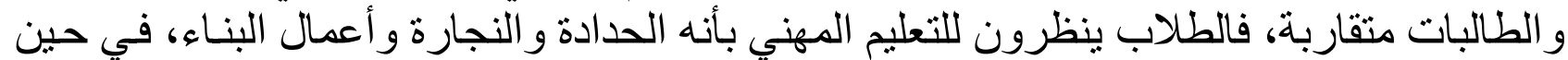

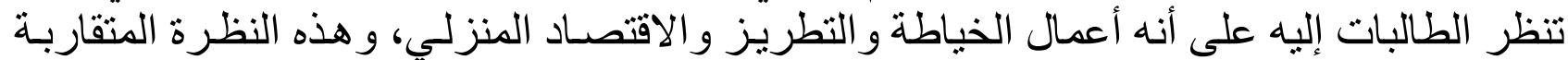
تشكل اتجاها متقاربا نحو التعليم المهني. التهري.

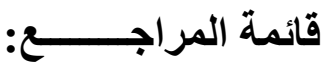

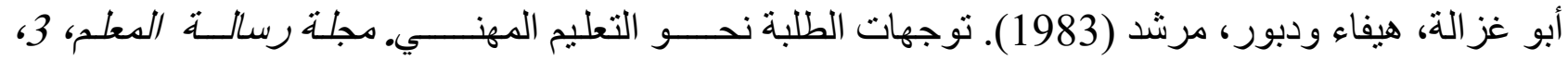

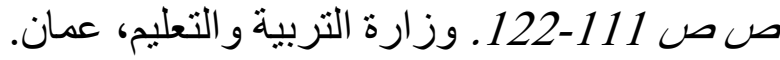




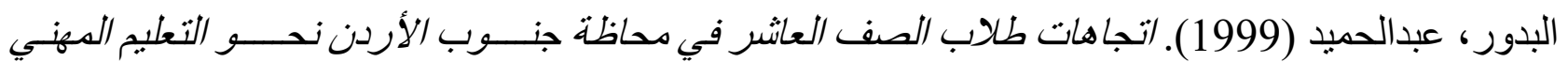

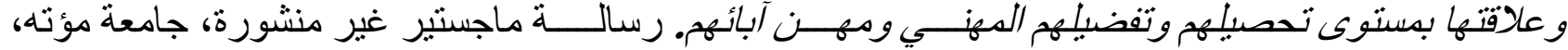
عمان.

البطارسة، منيرة عيسى (1992). اتجاهات طالبات مرحلة التعليم الأساسي نحو مبحث التربية المعنبة. رسالـة ماجستير غير منشـورة، الجامعـة الأردنية، عمـان.

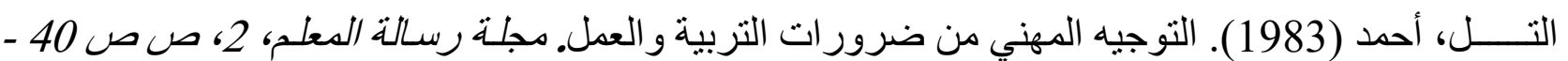
41. 4. وزارة التربية والتعليم، عمان.

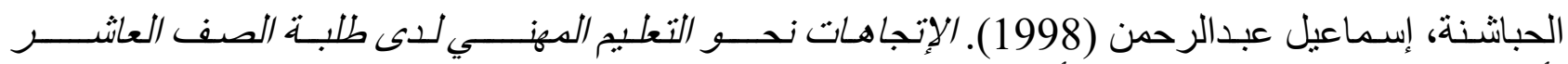

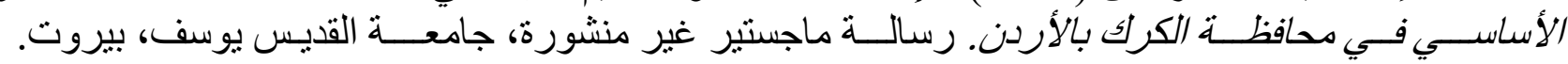
الحربي، مشعل بن فر اج بن فهد (2007). عزوف طلبة المرحلة الثانوبية في دولـة الكويت عن التعلبم المهني

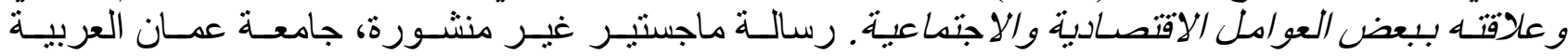

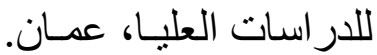
الحنيطي، مريم عبدالفتاح فلاح (2002). أثر رضا الأهل ومستواهم التعلبيسي ورغبة الطالبات والتوعية المهنية

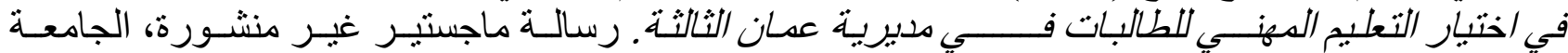
الأر دنية، عمان.

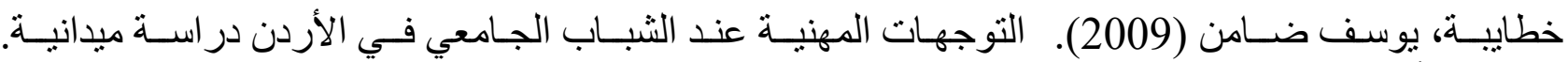

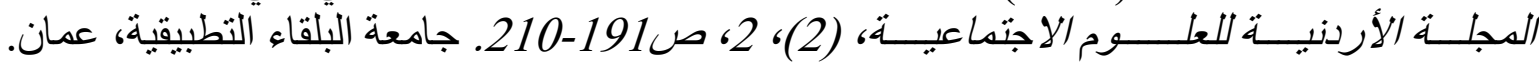

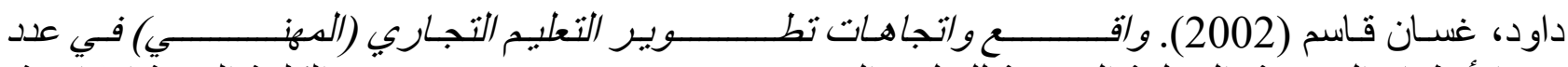

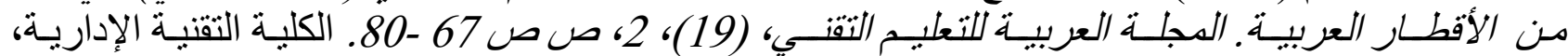

الريامي، أحمد بن جمعة وآخرون (2010). التربية وتنمبية الوعي السباحيـ السياسـيـ المهنـي. السيب: مكتبـة

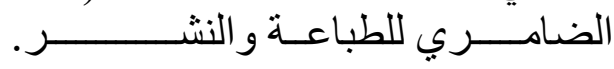

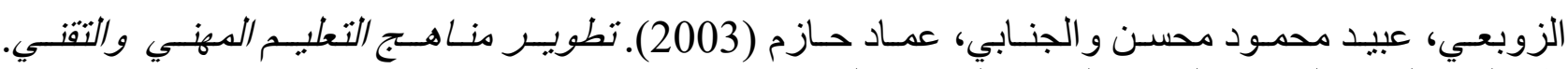

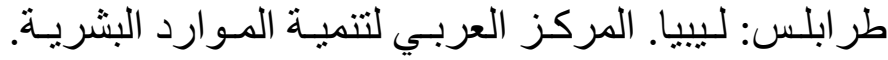

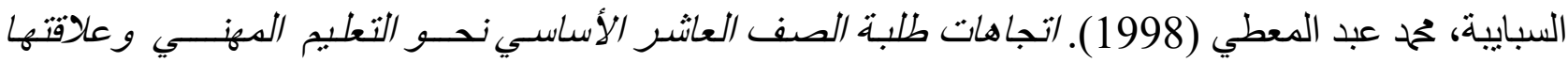

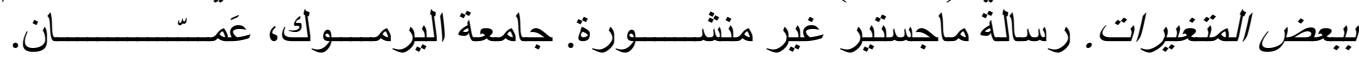
شمسان، أحمد والهيتي، خلف نصار (1999). الاتجاهات نحو التعليم المهنسي والتقني في البين. مجلتة البحوث

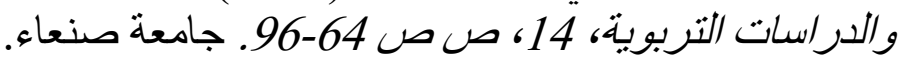

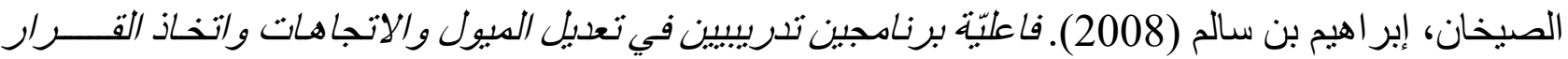

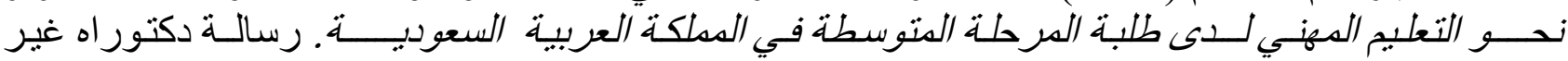

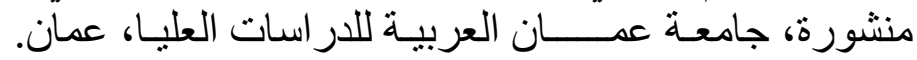
الطر اونة، نهى سليمان خليف (2000). العوامل المؤثرة علـى طلبة الصف العاثـــر الأساسـي الالتحاق بالتعليم

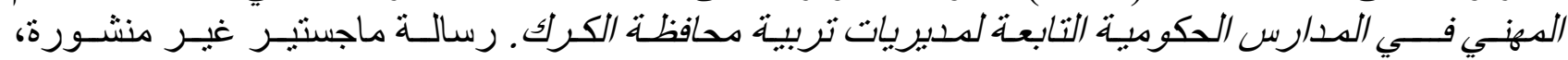
جامعـة مؤته، عمــان.

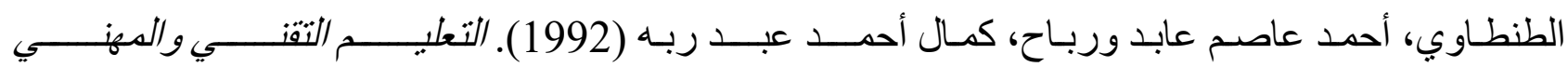
بسلطنة عدان ودوره في تحقيق التنديبة. مجلة التربية المعاصرة، (9)، 20، ص صد ص 9 - 37. القأهرة.

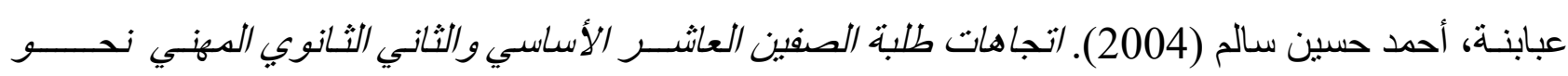




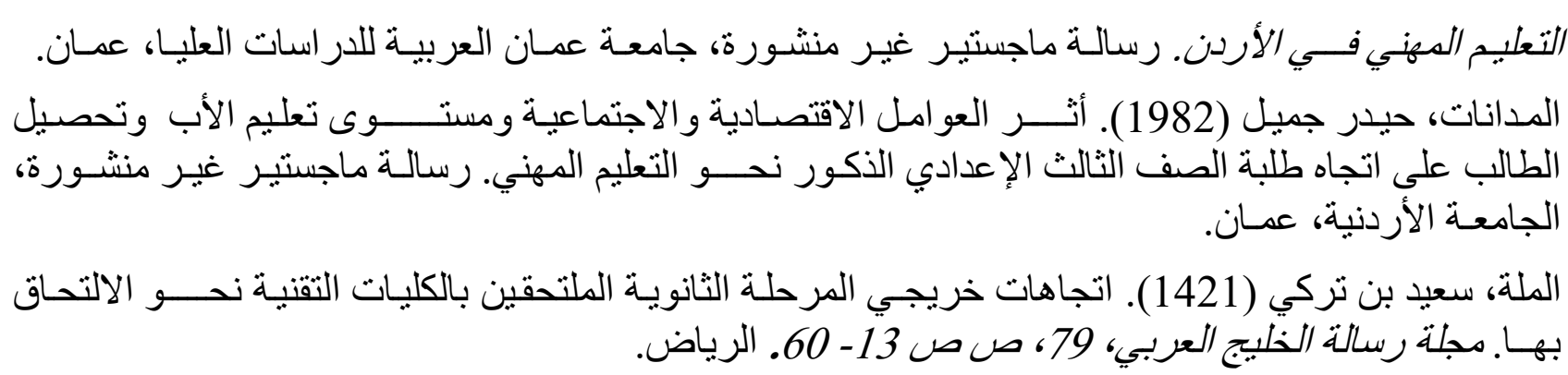

\section{ARABIC REFERENCES IN ROMAN ALPHABET}

'Abu Ghazalat, Hifa' Wadubur, Murshid (1983). Tawajuhat Altalabat Nahw Altaelim Almahnay. Majalat Rasalt Almaelim, 3, S S 111-122. Wizarat Altarbiat Waltaelimi, Eaman.

Albudur, Eabdalhmid (1999). Aitijahat Tullab Alsafi Aleashir Fi Muhazat Jinwib Al'urduni Nahw Altaelim Almahniu Waealaqatuha Bimustawaa Tahsilihim Watafdilihim Almahnay Wamahan Abayahim. Rasalat Majstayr Ghyr Manshurat, Jamieat Mutah, Eaman.

Albatarsat, Munirat Eisaa (1992). Aitijahat Talibat Marhalat Altaelim Al'asasii Nahw Mabhath Altarbiat Almahniati. Rasalat Majstir Ghir Munshwrat, Aljamieat Al'urduniyati, Euman.

Altl, 'Ahmad (1983). Altawjih Almahniu Min Darurat Altarbiat Waleamal. Majalat Risalat Almaelim, 2, S S 40 41. Wizarat Altarbiat Waltaelimi, Eaman. Alhabashnat, 'lismaeil Ebdalrihmn (1998). Al'iitjahat Nahaw Altaelim Almahnay Ladaa Tulbat Alsaf Aleashr Al'asasay Fay Mhafzt Alkrk Bial'urduni. Rasalat Majstayr Ghyr Manshurat, Jamet Alqadias Yusif, Bayrut.

Alharbi, Misheal Bin Firaj Bin Fahd (2007). Eazuf Tlbt Almarhalat Alththanawiat Fi Dawlat Alkuayt Ean Altaelim Almahnii Waealaqatih Bibaed Aleawamil Alaiqtisadiat Walaijtimaeiati. Rasalat Majstir Ghir Munshawirat, Jameat Euman Alerbyt Lildirasat Aleulya, Euman.

Alhaniti, Maryam Eabdalfatah Falah (2002). 'Athar Rida Al'ahl Wamustawahum Altaelimia Warighbat Altaalibat Waltaweiat Almihniat Fi Aikhtiar Altaelim Almahiny Liltaalibat Fay Mudiriat Eamman Althaalithatu. Rasalat Majstir Ghir Munshwrat, Aljamieat Al'urduniati, Euman.

Khataybt, Yusif Damin (2009). Altawajuhat Almahnit Eind Alshbab Aljamieii Fay Al'urdun Darasat Midanyt. Almjlt Alardnyt Lilealwim Alaijtimaeyt, (2), 2, Sa191-210. Jamieat Albalqa' Altatbiqiat, Eaman.

Dawid, Ghasan Qasim (2002). Waqe Waitijahat Ttwayr Altaelim Altjari (Almahny) Fy Eadad Min Al'aqtar Alerby. Almujlt Alerbyt Liltelim Altaqnyu, (19), 2, S S 67 -80. Alkuliyat Altaqniat Al'iidariati, Baghdad.

Alriyami, 'Ahmad Bin Jumeat Wakharun (2010). Altarbiat Watanmiat Alwaey Alsiyahy- Alsiyasy- Almahni. Alsyb: Maktabat Aldaamri Liltabaet Walnashr.

Alzubieiu, Eubayd Mahmud Muhsin Waljanabi, Eimad Hazim (2003). Tatwiar Munahj Altelym Almahnii Waltaqni. Tarablas: Lybya. Almarkaz Aleurbay Litanmiat Almaward Albashrit.

Alsabayibat, Muhamad Eabd Almaeti (1998). Aitijahat Tlbt Alsafi Aleashir Al'asasii Nahaw Altaelim Almahinay Waealaqatuha Bibaed Almutghayrat. Risalat Majstir Ghyr Manshwirat. Jamieat Alyarmwik, Eaman.

Shumasan, 'Ahmad Walhiti, Khalf Nsar (1999). Alaitijahat Nahw Altaelim Almahnii Waltaqnia Fi Alyamn. Majalat Albihawth Waldirasat Altarbawiat, 14, S S 64-96. Jamieat Sanea'.

Alsaykhan, 'librahim Bin Salim (2008). Faelyt Barnamajayn Tadribiiyn Fi Taedil Almuyul Walaitijahat Waitikhadh Alqarar Nahw Altaelim Almahniu Lidaa Tlbt Almarhalat Almutawasitat Fi Almamlakat Alearabiat Alsaeudi. Rasalat Dukturah Ghyr Manshurat, Jameat Eiman Alearbyt Lildirasat Alealya, Eamaan.

Altarawnat, Nahaa Sulayman Khalif (2000). Aleawamil Almuatharat Ealaa Tlbt Alsafi Aleashar Al'asasay Alailtihaq Bialtaelim Almahnii Fay Almadaris Alhukumiat Alttabieat Limudiriaat Tarbiat Muhafazat Alkark. Rasalat Majstir Ghir Munshawirat, Jamieat Mutih, Euman.

Altintawi, 'Ahmad Easim Eabid Warabah, Kamal 'Ahmd Eabd Rabih (1992). Altelym Altqny Walmhiny Bisiltanat Eamman Wadawruh Fy Thqyq Altnmy. Majalat Altarbiat Almueasiratu, (9), 20, S S 9 - 37. Alqahirat.

Eibabnat, 'Ahmad Husayn Salim (2004). Aitijahat Tlbt Alsafin Aleashar Al'asasia Walththani Althaanawi 
Almahni Nahw Altelym Almahnia Fay Al'urdunn. Rasalat Majstir Ghir Munshawirat, Jameat Euman Alerbyt Lildirasat Aleulya, Euman.

Almadanat, Haydar Jamil (1982). 'Athr Aleawamil Alaiqtisadiat Walaijtimaeiat Wamastwaa Taelim Al'abi Watahsil Altaalib Ealaa Aitijah Tlbt Alsafi Alththalith Al'iiedadii Aldhakawir Nahaw Altaelim Almahni. Rasalat Majstir Ghir Munshwrat, Aljamieat Al'urduniyati, Euman.

Almilat, Saeid Bin Trky (1421). Aitijahat Khryjy Almarhalat Alththanawiat Almultahaqin Bialkliyat Altaqniat Nhw Alailtihaq Biha. Majalat Risalat Alkhalij Alearabii, 79, S S 13- 60. Alriyad.

\section{REFERENCE LIST}

Gunderson, Margavetm (2004). Astudy of the influence Vocational Education has on students Utimate academic success. a non-published doctorate, the University of central Florida, U.S.

Iredia, D. S. (1986). Attitudes of urban students toward vocational education. Texas Southern University. ProQuest Dissertations and Theses, $105 \mathrm{p}$. Retrieved from:

McGillicuddy, D. W. (1989). Attitudes of secondary school students toward vocational education. State University of New York at Buffalo. ProQuest Dissertations and Theses, $127 \mathrm{p}$.

Zakaria, Abd.Rahman (1986).The attitudes of Students and their Parents towards Vocational Education. Jonral of Education, (9), 3, 234- 430. University Pertanian Malaysia. 